\title{
AVALIAÇÃO DOS EFEITOS DO ULTRA-SOM PULSADO DE BAIXA INTENSIDADE NA REGENERAÇÃO DE MÚSCULOS ESQUELÉTICOS COM VISTAS À APLICABILIDADE EM CLÍNICA FISIOTERAPÊUTICA
}

\author{
Dyjalma Antônio Bassoli
}

Dissertação apresentada ao Programa de Pós-Graduação Interunidades (Escola de Engenharia de São Carlos, Faculdade de Medicina de Ribeirão Preto e Instituto de Química de São Carlos) da Universidade de São Paulo, como parte dos requisitos para obtenção do título de Mestre em Bioengenharia.

ORIENTADOR: Affonso Luiz Ferreira 
Ficha catalográfica preparada pela Seção de Tratamento da Informação do Serviço de Biblioteca - EESC/USP

B322 Bassoli, Dyjalma Antônio

Avaliação dos efeitos do ultra-som pulsado de baixa intensidade na regeneração de músculos esqueléticos com vistas à aplicabilidade em clínica fisioterapêutica / Dyjalma Antônio Bassoli. -- São Carlos, 2001.

Dissertação (Mestrado) -- Escola de Engenharia de São Carlos/Faculdade de Medicina de Ribeirão Preto/Instituto de Química de São Paulo-Universidade de São Paulo, 2001.

Área: Bioengenharia.

Orientador: Prof. Dr. Affonso Luiz Ferreira.

1. Regeneração muscular. 2. Ultra-som pulsado de baixa intensidade. I. Título. 
...Há quem diga que todas as noites são de sonhos.

Mas há também quem garanta que nem todas, só as de verão.

Mas no fundo isso não tem muita importância.

$O$ que interessa mesmo não são as noites em si, são os sonhos.

Sonhos que o homem sonha sempre.

Em todos os lugares, em todas as épocas do ano, dormindo ou acordado...

William Shakespeare 
Dedico este trabalho a toda a minha família que me incentivou e me auxiliou em todos os momentos. Em especial à Maria Emília, minha filha e Ana Paula, minha esposa, os maiores motivos para vencer este desafio. 
Ao Dr. Affonso Luiz Ferreira.

"Há pensamentos que são orações, há momentos nos quais, qualquer que seja a posição do corpo, a alma está de joelhos".

Victor Hugo. 
"Tudo que tenho recebi de Deus; - de que queres me envaideça?"

Zálkind Platigórsky

Quando se consegue chegar ao final do trabalho proposto, pode-se sentir o peso das contribuições dadas por pessoas que ao ajudarem, mesmo supondo serem contribuições simples ou obrigações, muitas vezes não avaliam o peso de suas atitudes para quem as recebeu. Minha profunda gratidão a todos que, direta ou indiretamente, contribuíram para a elaboração deste trabalho e particularmente:

A Ana Rosa Crisci, pela ajuda em todas as etapas deste trabalho. "No caráter, na conduta, no estilo, em todas as coisas, a simplicidade é a suprema virtude" (Henry Wadsworth Longfellow).

A Carmen Aparecida Malagutti Barros, que por um destes felizes "acasos" que ocorrem em nossas vidas, me solicitou companhia para estar em São Carlos em um determinado dia que viria a culminar neste trabalho.

Ao Dr. José Marcos Alves que, naquele dia, sugeriu que eu procurasse pelo Dr. Affonso Luiz Ferreira.

A Ana Maria Araújo Ferreira, Eunice de Oliveira Marques e Luiz César Manetti pelas aulas de física e matemática gentilmente oferecidas.

Ao amigo Paulo de Tarso Camilo de Carvalho pela ajuda nas primeiras traduções, e na sua pessoa estendo o agradecimento a todos aqueles que junto conosco estiveram cursando as disciplinas teóricas na EESC e FMRP, especialmente à Elizabete Dias Flausino Gaspar Gomes.

Ao José Luís Soares obrigado pela disponibilidade e pelo excelente trabalho na preparação das lâminas histológicas.

A Dr ${ }^{\mathrm{a}}$. Catarina Satie Takahashi do Departamento de Genética da USP, pela cessão da colchicina.

Ao Dr. Orivaldo Lopes da Silva pela ajuda quando da procura da colchicina e pelas informações sobre o Ultra-som.

Aos funcionários das Secretarias da Bioengenharia (São Carlos e Ribeirão Preto), em especial à D. Marielza e Janete.

Aos diretores, docentes, discentes e funcionários da UNICLAR Unidade Batatais -SP, pelo apoio e pela confiança. trabalho.

A Regina M. R. Pupin pelo trabalho de digitação e formatação deste

A Prof ${ }^{\mathrm{a}}$. Carolina Luiza Pippa Tomazella Videira pelo auxílio na confecção do abstract.

À Fisioterapia que tem realizado os meus sonhos e os da minha família. 


\section{SUMÁRIO}

LISTA DE FIGURAS

LISTA DE TABELAS

RESUMO

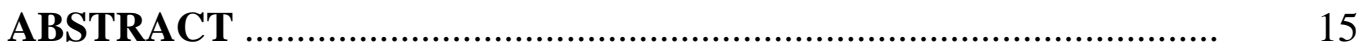

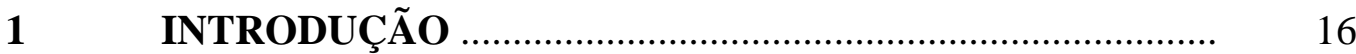

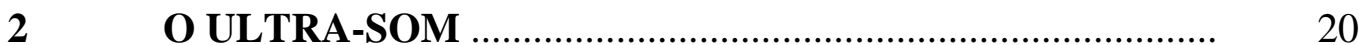

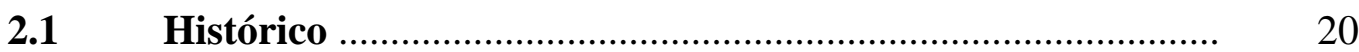

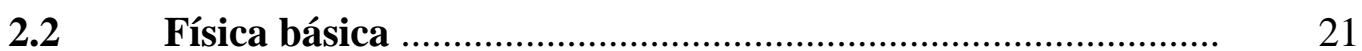

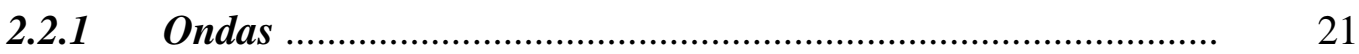

2.2.2 Características das ondas ultra-sônicas .................................... 22

2.2.2.1 Velocidade de propagação $(c)$................................................... 24

2.2.2.2 Intensidade e campo acústico ....................................................... 24

2.2.23 Modos de propagação .............................................................. 26

2.2.3 Impedância acústica ............................................................... 27

2.2.4 Reflexão e Refração ................................................................. 28

2.2.5 Interferências e Ondas Estacionárias ........................................ 29

2.2.6 Mecanismos de atenuação .................................................... $\quad 30$

2.2.7 Transdutores ................................................................. 31

2.3 Mecanismos de interação do ultra-som com células e tecidos biológicos ................................................................. $\quad 32$

2.3.1 Mecanismo térmico ................................................................ 33

2.3.2 Mecanismos não-térmicos ..................................................... 35

2.3.2.1 Cavitação ............................................................................. 35

2.3.2.1.1 Cavitação transiente ................................................................ 36

2.3.2.1.2 Cavitação estável ...................................................................... 36

2.3.2.2 Fluxo e Microfluxo ..................................................................... 37

2.3.2.3 Piezoeletricidade ……................................................... $\quad 38$ 
3 O TECIDO MUSCULAR …........................................... 40

3.1 Características morfológicas e funcionais do músculo ........... 40

3.2 O músculo estriado esquelético ................................................. 42

3.3 Visualização das principais estruturas do tecido muscular .. 50

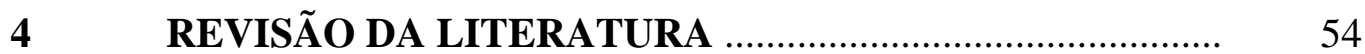

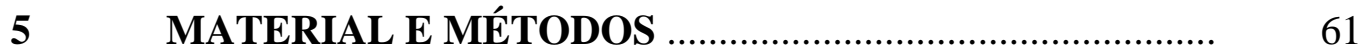

5.1 Animais de experimentação ................................................. 61

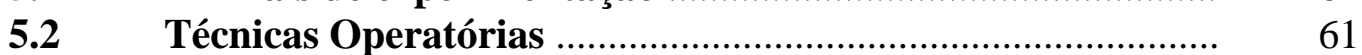

5.3 Estímulo ultra-sônico............................................................... 64

5.4 Elaboração do tecido muscular para o estudo histológico..... 65

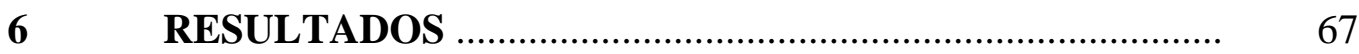

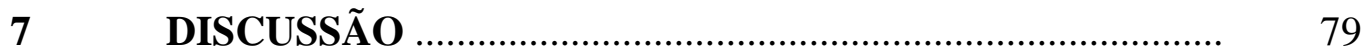

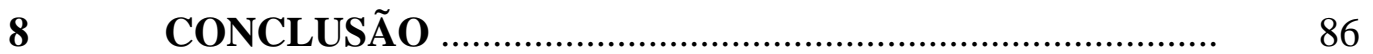

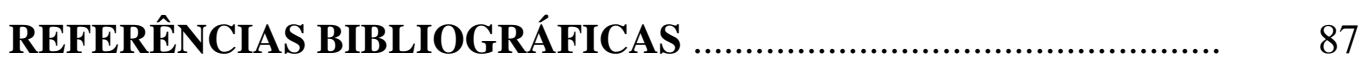




\section{LISTA DE FIGURAS}

FIGURA 01- Modo de propagação das ondas ultra-sônicas.

FIGURA 02 - Deslocamento de uma partícula em função da distância e do tempo

FIGURA 03 - Variação da intensidade acústica (I) nos campos ultrasônicos próximos e distantes, em meio aquoso. Na parte "a" tem-se a variação de I ao longo do eixo x, na parte " $b$ " temse a variação de I ao longo do eixo y (perpendicular à página), e na parte "c", o valor da intensidade média ao longo do eixo y, para uma determinada posição

FIGURA 04 - Sinal senoidal pulsado............................................................ 26

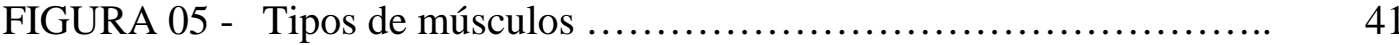

FIGURA 06 - Esquema ilustrativo da origem embriológica de uma fibra muscular esquelética.

FIGURA 07 - Esquema ilustrativo da arquitetura de um músculo esquelético

FIGURA 08 - Esquema ilustrativo de um sarcômero e seus componentes ... 46

FIGURA 09 - Corte longitudinal de uma fibra de músculo estriado

FIGURA 10 - Representativo de um corte transversal de fibras musculares estriadas

FIGURA 11 - Corte transversal de fibras musculares estriadas

FIGURA 12- Anestesia mediante injeção intraperitoneal

FIGURA 13 - Incisão dos planos superficiais

FIGURA 14 - Demonstrativos das incisões praticadas no músculo glúteo maior 
FIGURA 15 - Demonstrativo da síntese dos planos muscular e superficiais 63

FIGURA 16 Sinal elétrico que excita o transdutor ultra-sônico pulsado....

FIGURA 17 - O aparelho de ultra-som pulsado

FIGURA 18 - Figura representativa de estimulação estática com o transdutor ultrasônico

FIGURA 19 - As fotomicrografias A e C correspondem a áreas de necrose de músculos de animais controles (sem estímulo) após 3 e 6 dias, respectivamente. As fotomicrografias $B$ e $D$ representam as mesmas áreas de necrose em músculos de animais estimulados por 3 dias com o ultra-som pulsado. Notar, acima, a intensa proliferação de vasos neoformados $(\emptyset)$,em meio a restos de fibras musculares $(\Rightarrow)$ e uma diminuição do infiltrado inflamatório $(\square)$. Alguns animais estimulados (B e D), já apresentam fibroblastos ( $\bullet$ ) e início de formação de miotubos $(\Rightarrow)$. Cortes de $6 \mu \mathrm{m}$, corados pelo H.E. Aumento A, C e D de 192x; B de 384x; nos destaques aumento de $288 \mathrm{x}$

FIGURA 20 - As fotomicrografias da figura ilustram o músculo de 2 animais controles (A e C) e de 2 animais estimulados pelo ultra-som pulsado (B e D) durante 10 dias. Nos animais controles há ainda necrose em evolução (círculo), nos animais estimulados há intensa neovascularização( ()$)$, início de migração de células satélites para restos de membranas, visando a formação de miotubos $(\Longrightarrow)$ e a formação de fibroblastos $(\square$.Cortes de $6 \mu \mathrm{m}$ corados pelo H.E.. Aumento: A, B e C de 192x e D de 480x.

FIGURA 21 - As fotomicrografias são demonstrativas das diferentes células de tecido muscular com 3 dias cujos núcleos em divisão foram bloqueados pela colchicina. $\mathrm{Na}$ foto $\mathrm{A}$ indicativo de músculo de animal não estimulado cuja lesão acha-se em fase inflamatória $(\square)$. Na foto B, de um animal estimulado, estão indicadas metáfases de núcleos de células satélites em divisão (mioblastos) $(D)$. Na foto $\mathrm{C}$ mioblastos, também de animal estimulado, agregando-se para constituir miotubos $(\Longrightarrow)$. Cortes de $6 \mu \mathrm{m}$ corados pelo H.E. Aumento: A e $\mathrm{C}$ de $480 x$ e $B$ de $1200 x$

FIGURA 22 - Fotomicrografias de células musculares normais, distantes da área de lesão com 10 dias. A foto A mostra células musculares não estimuladas( $\square$ ). A foto $B$, trata-se de músculo estimulado, mostrando um núcleo de célula satélite em metáfase (⿻上丨 Notar que o núcleo acha-se isolado da sarcolema da célula. Cortes de $6 \mu \mathrm{m}$ corados pelo H.E. Aumento de 480x 
FIGURA 23 - Fotomicrografias de miotubos $(\Rightarrow$ de músculos de animais estimulados pelo ultra-som pulsado por 10 dias consecutivos. Apresentam várias metáfases de núcleos de células miogênicas ( $\square$ ), miotubos com numerosos núcleos enfileirados. Cortes de $6 \mu \mathrm{m}$ corados pelo H.E.. Aumento: A e D de 480x; B e C de 192x

FIGURA 24 - Fotomicrografia de uma célula muscular estimulada por 10 dias e formando miofibrilas tendendo a se constituir numa célula muscular normal. Corte de $6 \mu \mathrm{m}$ corados pelo H.E.. Aumento de 480x e no destaque de 720x....

FIGURA 25 - Vasos neoformados induzidos pela ação do ultra-som pulsado em músculo estimulado por 3 dias, com conseqüente aceleração da inflamação. Aumento de 1200x... 


\section{LISTA DE TABELAS}

TABELA 01- Propriedades acústicas típicas de vários meios

TABELA 02- Coeficiente de absorção $(\alpha)$ em diferentes tecidos para a frequiência de $1 \mathrm{Mhz}$ 


\section{RESUMO}

BASSOLI, Dyjalma Antônio. Avaliação dos efeitos do ultra-som pulsado de baixa intensidade na regeneração de músculos esqueléticos com vistas à aplicabilidade em clínica fisioterapêutica. São Carlos, 2001. 94 p. Dissertação (Mestrado em Bioengenharia) - Escola de Engenharia de São Carlos, Faculdade de Medicina de Ribeirão Preto e Instituto de Química de São Carlos, Universidade de São Paulo.

Foi utilizado na presente pesquisa o ultra-som pulsado de baixa intensidade, com a finalidade de avaliar, experimentalmente, seus efeitos físicos sobre a regeneração do músculo esquelético de ratos. Foram empregados no experimento 10 animais de ambos os sexos. Após eleição do músculo glúteo maior, foram feitas incisões perpendiculares (pós anestesia) às suas fibras, alcançando aproximadamente dois terços de sua espessura. Seguinte às incisões, realizou-se síntese do músculo e dos planos superficiais. Foi convencionado estudar os efeitos do ultra-som pulsado após 3, 6 e 10 dias de estímulo. Antes do sacrifício dos animais foi-lhes administrado Colchicina, com a finalidade de bloquear aa células em divisão. Mediante análise histopatológica comparativa dos músculos, constatou-se que enquanto nos animais não estimulados desenvolveu-se, aos 3 dias, áreas de necrose e inflamação, naqueles estimulados houve uma diminuição das mesmas. Além disso, nos animais estimulados, ocorre intensa neovascularização nas áreas de lesão. Observou-se também uma migração de células miogênicas (satélites) para restos de bainhas remanescentes de fibras musculares regeneradas. Constatou-se um aumento de mioblastos com núcleos em metáfase. Aos 10 dias, os animais estimulados exibiam inúmeros miotubos com formação de miofibrilas, caracterizando células musculares em franca maturação. Longe da área estimulada, o ultra-som foi capaz de induzir mitoses em células satélites. Notou-se que os efeitos do ultra-som pulsado aceleram a regeneração de fibras musculares mediante uma intensa neoformação vascular, acelerando a reparação da necrose e formação de mioblastos, os quais agregam-se em miotubos formando novas células.

Palavras-chave : regeneração muscular; ultra-som pulsado de baixa intensidade. 


\begin{abstract}
BASSOLI, Dyjalma Antônio. Evaluation of the effects of low intensity pulsed ultrasound on skeletal muscle regeneration having in mind its applicability to physiotherapeutic clinic. São Carlos, 2001. 94 p. Dissertação (Mestrado em Bioengenharia) - Escola de Engenharia de São Carlos, Faculdade de Medicina de Ribeirão Preto e Instituto de Química de São Carlos, Universidade de São Paulo.
\end{abstract}

It was used in the present research the low intensity pulsed ultrasound with aim of evaluating, experimentally, its physical effects on the regeneration of rats skeletal muscle. Ten male and female animals were used in this experiment. After election of the gluteus maximus muscle, perpendicular incisions were made (after anesthesia) in its fibers, reaching approximately two thirds of its thickness. After the incisions, a synthesis of the muscles and superficial plans was performed. It was established to study the effects of the pulsed ultrasound after 3, 6 and 10 day-stimuli. Before sacrificing the animals Colchinine was given aiming to block cells in division. By means of comparative histopathological analysis of the muscles, it was verified that in non-stimulated animals an area of necrosis developed in three days, while in those that were simulated there was a decrease of the same. Moreover, on the stimulated animals, there is intense neovascularization in the damaged area. A migration of myogenic cells (satellites) to rests of remaining sheaths from regenerated muscle fiber was also observed. It was verified an increase of myoblasts with nuclei in metaphase. In ten days, the stimulated animals showed countless myotubes with formations of myofibrils, characterizing mature muscle cells. Far from the stimulated area, the ultrasound was able of inducing mitosis to satellite cells. It was noticed that the effects of the pulsed ultrasound accelerate muscle fiber regeneration by means of an intense vascular neoformation, accelerating the restoration of the necrosis and the formation of myoblasts, which aggregates in myotubes forming new cells.

Keywords: muscle regeneration; low intensity pulsed ultrasound. 


\section{INTRODUÇÃO}

A 22 de Agosto de 1999, o atleta americano Maurice Greene, conseguiu a marca de $9.80 \mathrm{~s}$ para percorrer os 100 metros em linha reta, tornando-se o homem mais veloz do mundo. Pode-se perguntar quais os fatores predisponentes para essa performance. Aí, perder-se-ia em uma série de cogitações, mas um dos fatores primordiais, certamente será o fisiológico: as fibras musculares deste fabuloso atleta, especialmente as das suas coxas, contribuíram por um lapso de tempo extremamente curto, maior força que de seus competidores.

Naturalmente, se se voltar para o lado esportivo, as pesquisas estão quase sempre envolvidas na capacidade dos músculos adaptarem-se a diferentes desafios, quer o desempenho em uma maratona quer na explosão muscular na largada de uma corrida.

O músculo esquelético é o tecido mais abundante do nosso corpo e um dos que podem causar grandes adaptações. Exercícios podem aumentar o músculo em sua secção fisiológica de 2 a 3 vezes, podem sofrer um encurtamento de cerca de $20 \%$ em pouco tempo, garantindo um aumento do seu trabalho e da sua potência.

A quantidade e qualidade de fenômenos bioquímicos para que o músculo consiga tais adaptações é extremamente complexa. A composição material de um músculo proporciona-lhe a velocidade de contração dependendo da qualidade e quantidade na composição de suas fibras. As fibras de contração lenta dependem relativamente mais de um metabolismo aeróbico eficiente, enquanto que as fibras 
rápidas dependem mais de um metabolismo anaeróbico. As fibras de contração lenta destinam-se a trabalhos mais prolongados (como maratonas, natação em provas de longa distância), enquanto que as fibras de contração rápida estão relacionadas a trabalhos intensos e de curta duração. Na espécie humana há músculos que apresentam contingentes de fibras rápidas e lentas, na mesma proporção, como no quadríceps. Entretanto existem grandes variações entre pessoas na proporção da qualidade de fibras. Existem também fibras híbridas contendo miosina das duas espécies em proporções iguais.

Duas das mais fundamentais áreas do estudo em pesquisa sobre músculos esqueléticos estão ligadas diretamente à performance atlética, procurando a melhor maneira de hipertrofiar a musculatura e como esta atividade poderia converter um tipo de fibra em outro.

O outro aspecto de grande relevância é o relacionado à regeneração muscular correlacionada à resposta das células satélites, ditas células precursoras musculares. Acredita-se que o exercício rigoroso conduz ao aparecimento de microrupturas de fibras musculares. A área danificada atrairia células precursoras (satélites), que se incorporariam ao tecido muscular e iniciariam a produção de proteínas para preencher o intervalo lesado. Estes núcleos tornar-se-iam indistintos dos núcleos próprios das células musculares. Com esses núcleos adicionais, as fibras ficariam aptas a produzir mais proteínas e criar novas miofibrilas. A criação de proteínas seria decorrente de gene nuclear e o processo mediante o qual a informação passaria do núcleo para o citoplasma, onde a proteína deverá ser produzida inicia com uma transcrição (ANDERSEN et al., 2000).

Desde 1960, pesquisas foram conduzidas no sentido de converter fibras lentas em fibras rápidas (BUELLER et al. apud ANDERSEN et al., 2000) mediante inversão de inervação procurando transpor nervos destinados a músculos de fibras lentas para músculo de fibras rápidas de modo a controlar fibras de tipos opostos. Os autores relatam que um componente da molécula de miosina, a cadeia denominada pesada, determina as características funcionais da fibra muscular. Em um adulto, esta cadeia pesada existe em três variedades diferentes, que são designadas como I, IIa, 
IIx. As fibras do tipo I, também são conhecidas como fibras lentas; as fibras tipo IIa tipo IIx são chamadas fibras rápidas. São assim classificadas por uma boa razão: a velocidade de contração máxima da fibra tipo I é aproximadamente um décimo da fibra tipo IIx. A velocidade da fibra tipo IIa está entre as de tipo I e IIx.

Pesquisadores procuraram demonstrar se a possibilidade de fibras musculares transmudarem-se em tamanho e tipo, referida como "plasticidade" muscular, fosse também aplicável ao homem. Um exemplo extremo é o caso de paraplégicos, sem estímulo muscular levado a uma perda extrema de tecido. Mas, surpreendentemente, o tipo de músculo muda dramaticamente. Estes indivíduos paralisados experimentam um decréscimo agudo de quantidade de miosina lenta, enquanto que a quantidade de miosina rápida realmente aumenta. Após longo período predomina a miosina rápida no quadríceps, relembrando que em indivíduos sadios a proporção de miosina rápida e lenta no quadríceps é de $50 \%$. Levantou-se a hipótese que a ausência de estímulo nervoso pela ativação elétrica seria necessária para manter a relação de miosina.

A conversão de fibras não se restringe a indivíduos com paralisias musculares. Quando o indivíduo é submetido a exercícios de força repetidamente com pesos programados, o número de fibras rápidas (IIx) declina, pois se convertem em rápidas (IIa). Ao mesmo tempo as fibras aumentam sua produção de proteínas e se espessam (ANDERSEN et al., 2000).

Conquanto essas pesquisas conduzidas no sentido de modificar a composição muscular levantando até a hipótese de injeções de DNA no músculo estejam em andamento, discute-se muito ainda sobre os mecanismos da regeneração muscular.

Qualquer dispositivo, de preferência não invasivo, que assegurasse uma aceleração do reparo do músculo lesado, seria altamente desejável. Vive-se uma época em que a competição esportiva e o culto ao corpo estão amplamente exacerbados. Não obstante, as atividades modernas, os esportes radicais e o desempenho da atividade motora levam ao aparecimento de lesões musculares, mais ou menos graves, que certamente conduzem a uma perda de atividades, as quais 
dariam como somatório, um grande prejuízo funcional e mesmo de natureza econômica. A possibilidade de, mediante estímulos físicos não invasivos como o Ultra-Som Pulsado (USP) de baixa intensidade (1 a 5\% da intensidade do ultra-som fisioterapêutico), poder abreviar ou acelerar a reparação de lesões musculares, foi o fator que levou a empreender a presente pesquisa.

Este trabalho tem pois, como finalidade precípua, demonstrar experimentalmente os efeitos do USP de baixa intensidade, como o utilizado no tratamento de fraturas, na regeneração do músculo esquelético de ratos. 


\section{O ULTRA-SOM}

\subsection{Histórico}

Durante o século XIX foi demonstrado que o ouvido humano é capaz de detectar sons cujas freqüências de ondas estejam entre $16 \mathrm{~Hz}$ e $21 \mathrm{kHz}$, aproximadamente. No início do século XX, conseguiu-se produzir e detectar ondas sonoras com frequiência acima deste limite, audível pelo homem, dando origem ao termo Ultra-som (OKUNO, CALDAS \& CHOW, 1986).

A primeira aplicação prática do ultra-som foi em 1917 com a criação de sonares para a detecção de submarinos, utilizando o método pulso-eco. Alguns anos mais tarde, descobriu-se que o ultra-som produzia aumento da temperatura em tecidos biológicos, entre 1930 e 1940 ele foi introduzido na prática médica como um recurso terapêutico, usado particularmente para produzir calor em tecidos profundos.

De 1940 até os dias atuais, o ultra-som vem sendo extensamente usado em áreas médicas e industriais, e novos efeitos e aplicações do ultra-som vem sendo pesquisados. 


\subsection{Física básica}

\subsubsection{Ondas}

As ondas ultra-sônicas possuem uma freqüência que varia em torno de 20.000 e 20.000 .000 de ciclos por segundo ( 1 ciclo $=1$ hertz), que se propaga como uma onda de pressão causando agitação nas moléculas do meio em que estão se propagando, fazendo-as oscilarem, quer o meio seja sólido, líquido ou gasoso (TER HAAR, 1987). O ultra-som é transmitido em forma de ondas de compressão, onde a oscilação de partículas se dá paralelamente à direção de propagação da onda, constituindo zonas de compressão e rarefação; ou em forma de ondas de cisalhamento (somente para sólidos), onde as partículas oscilam em direção perpendicular à direção de propagação das ondas.

As ondas ultra-sônicas são ondas mecânicas e transmitem energia através da matéria causando uma oscilação nas posições de equilíbrio das suas partículas. Estes movimentos oscilatórios são resistidos por forças elásticas de acordo com a estrutura molecular do meio (FREDERICK, 1965).

Nos meios sólidos podem ser produzidas ondas de três tipos: longitudinal, transversal e superficial. A onda longitudinal ou depressão se caracteriza por causar oscilações nas partículas na mesma direção de propagação da onda. A onda transversal causa oscilações nas partículas em direção perpendicular à direção de propagação da onda, e a onda superficial causa oscilações elipsoidais nas partículas. Nos meios líquidos e gasosos podem ser produzidas ondas apenas do tipo longitudinal (WELLS, 1977). 


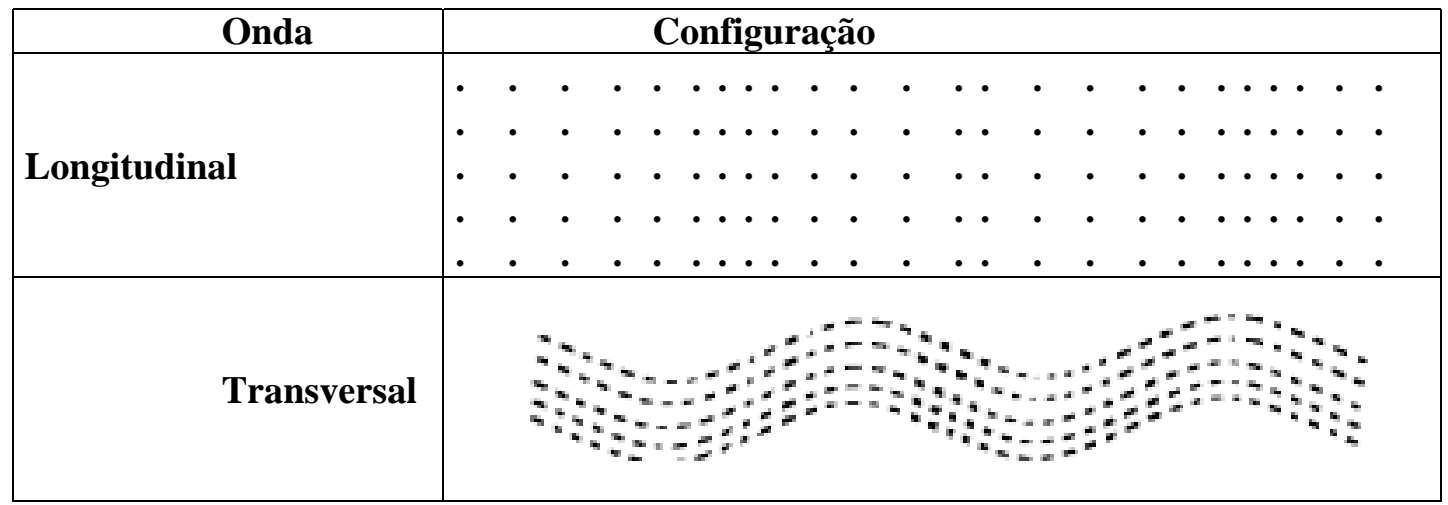

FIGURA 1 - Modo de propagação das ondas ultra-sônicas

Devidos ao fato dos tecidos moles do corpo humano serem considerados como um fluido, no presente trabalho serão consideradas somente as ondas ultrasônicas do tipo longitudinal.

\subsubsection{Características das ondas ultra-sônicas}

As ondas ultra-sônicas apresentam características dos demais tipos de ondas, como o comprimento, a amplitude, o período e a frequiência (TER HAAR, 1987).

O comprimento da onda $(\lambda)$ corresponde a distância entre regiões adjacentes de compressão ou de rarefação máxima, cujas partículas encontram-se em um mesmo estado de movimento, em um dado instante de tempo.

Amplitude (A) - corresponde ao deslocamento máximo que uma partícula experimenta à partir de sua posição de equilíbrio. Descreve a magnitude do distúrbio causado pela onda.

Período (T) é o intervalo de tempo necessário para que uma partícula realize um ciclo completo de movimento. 
Potência $(\mathrm{P})$ - energia (E) total do feixe em um intervalo de tempo (t), expressa em Watts.

A freqüência (f) corresponde ao número de vezes que uma partícula realiza um ciclo oscilatório por unidade de tempo.
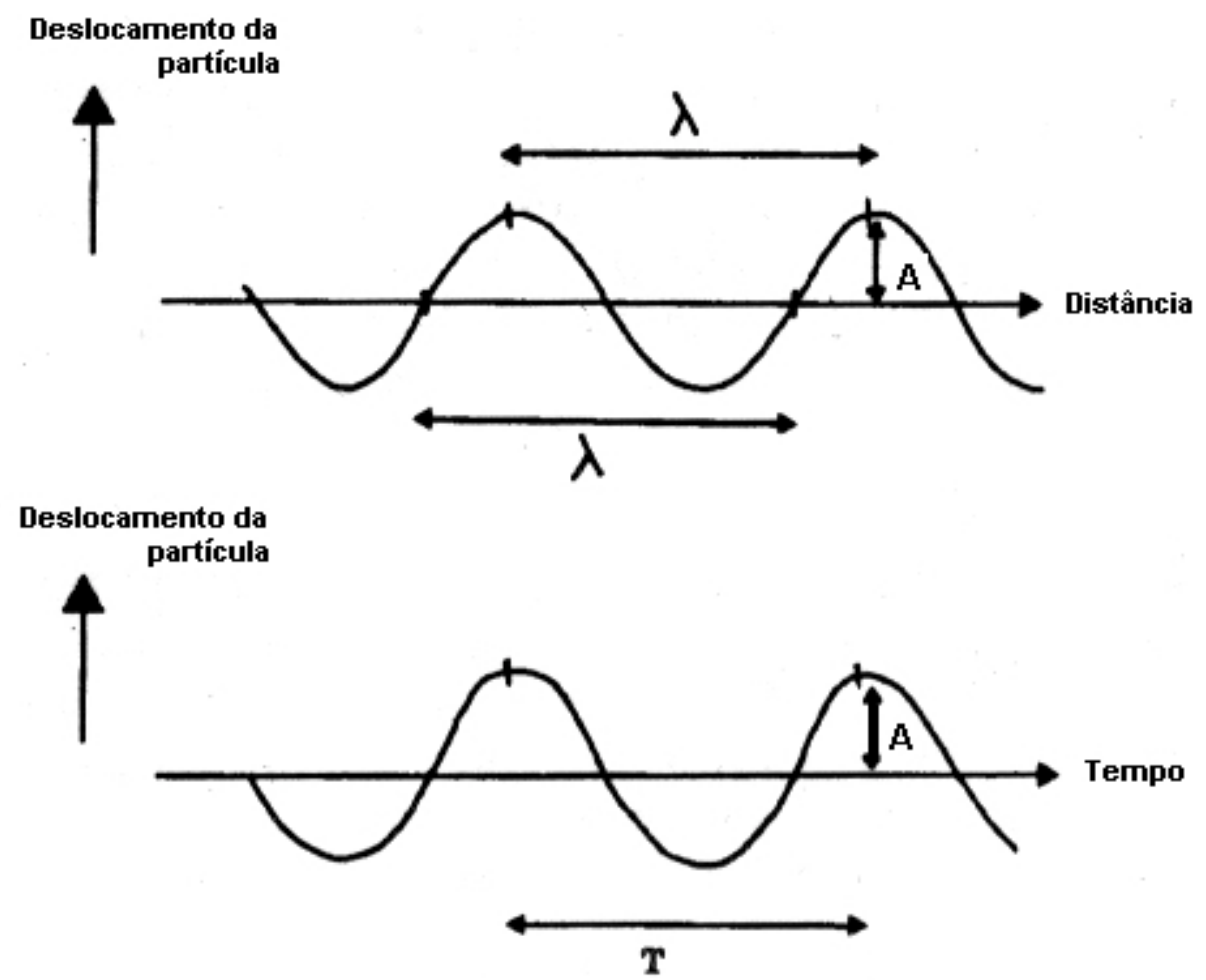

$\lambda=$ Comprimento de onda $A=$ Amplitude $\quad T=$ Período

FIGURA 2 - Deslocamento de uma partícula em função da distância e do tempo (TER HAAR, 1978). 


\subsubsection{Velocidade de propagação (c)}

A velocidade de propagação de uma onda (c) é definida como a distância percorrida pela onda ultra-sônica por unidade de tempo.

No entanto, a velocidade de onda ultra-sônica depende do tipo de onda considerada e das constantes elásticas do meio em que se propaga.

A velocidade de propagação das ondas sonoras decresce dos meios sólidos para os líquidos e destes para os gasosos. Nos tecidos moles do corpo humano a velocidade de propagação da onda ultra-sônica está ao redor de $1.500 \mathrm{~m} / \mathrm{s}$ (YOUNG, 1990).

\subsubsection{Intensidade e campo acústico}

Intensidade (I) - quando uma onda atravessa um meio, as partículas do meio começam a vibrar e adquirem energia cinética. A energia associada com a onda ultra-sônica é chamada de intensidade acústica e pode ser definida como a energia (E) que atravessa uma área (S) em um intervalo de tempo (t). (TER HAAR, 1987).

A energia fornecida pelas ondas ultra-sônicas ao atravessar o meio é medida pela intensidade acústica. Esta é definida como a razão média do fluxo de energia que atravessa uma unidade de área pela unidade de tempo (Watts $/ \mathrm{cm}^{2}$ ) (WELLS, 1977).

Os valores de intensidades descritos na literatura referem-se geralmente a intensidade transmitida pelo transdutor, e não a intensidade "in situ", pois esta é difícil de ser medida, embora possa ser calculada teoricamente (ZISKIN, 1985). 
A intensidade que caracteriza o campo acústico transmitido pelo transdutor é medida através de dosímetros de ultra-som em um meio de baixa atenuação normalmente em água. Esses dosímetros medem a "força de radiação" (F), possibilitando assim o cálculo da potência acústica $(\mathrm{P})$ e conseqüentemente da intensidade acústica temporal e espacial média, que é definida como o quociente entre a potência acústica total transmitida e a área do transdutor.

A intensidade apresenta características diferentes no campo acústico, caracterizando no campo duas regiões distintas: o campo próximo ou zona de Fresnel e o campo distante ou zona de Fraunhofer. No campo próximo a intensidade é disforme, enquanto no campo distante ela decresce suavemente com a distância da fonte, como ilustra a Figura 3.
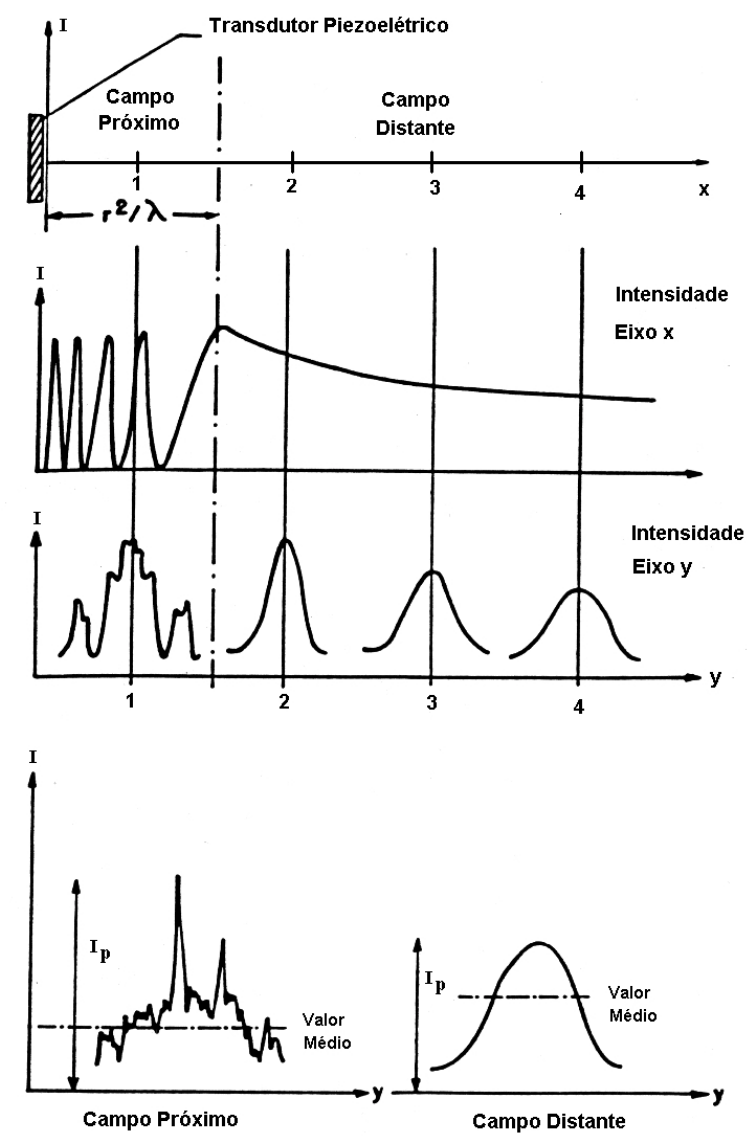

FIGURA 3 - Variação da intensidade acústica (I) nos campos ultra-sônicos próximos e distantes, em meio aquoso. Na parte "a" tem-se a variação de I ao longo do eixo x, na parte "b" tem-se a variação de I ao longo do eixo y (perpendicular à página), e na parte "c", o valor da intensidade média ao longo do eixo y, para uma determinada posição (ALVES, 1988 - adaptado de TER HAAR, 1978). 


\subsubsection{Modos de propagação}

As ondas ultra-sônicas podem se propagar de dois modos, o contínuo e o pulsado, a diferença entre estes dois modos está na interrupção da propagação de energia.

No modo contínuo não ocorre esta interrupção, havendo portanto um depósito ininterrupto de energia sobre os tecidos irradiados.

No modo pulsado, no entanto, há interrupções freqüentes na propagação de energia. Na utilização do modo pulsado há portanto dois tipos de freqüências a serem consideradas a freqüência da onda (f) citada anteriormente, e a frequiência de repetição de pulso (Fr), como ilustra a Figura 4.

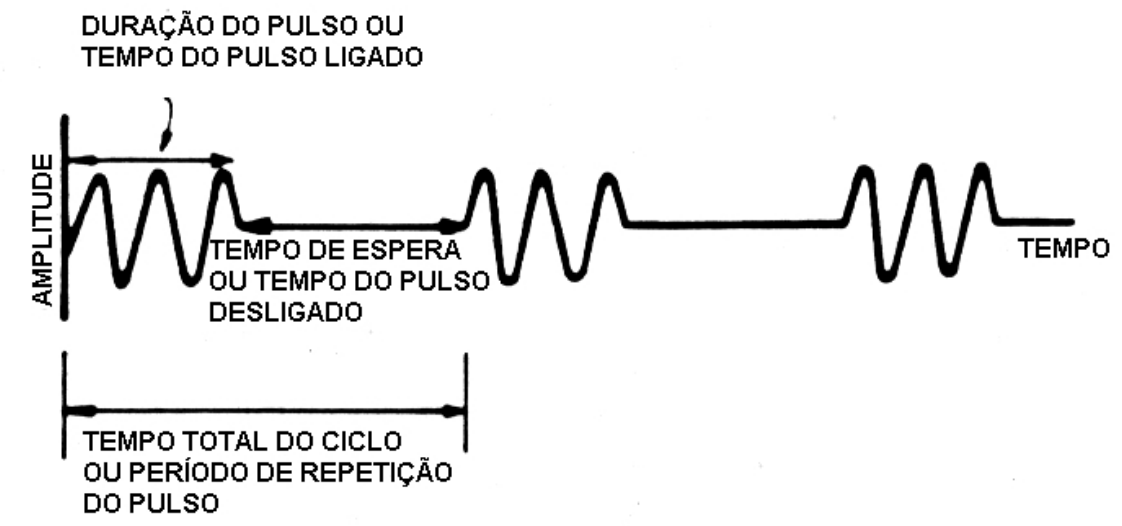

FIGURA 4 - Sinal senoidal pulsado. (HIKES et al., 1985). 


\subsubsection{Impedância acústica}

Impedância acústica $(Z)$ - é a propriedade de um meio se opor à vibração de suas partículas frente à passagem de ondas ultra-sônicas. Indica a propriedade que as ondas têm de se deslocarem mais facilmente em alguns meios que em outros.

A impedância acústica pode ser expressa de diferentes formas (FREDERICK, 1965). No entanto, usa-se comumente a impedância acústica característica do meio ou condutância acústica, que é obtida pelo produto da intensidade do meio pela velocidade do som no mesmo $(Z=\rho$. c).

A impedância acústica do meio é considerada como constante, visto que, a velocidade do som no meio é basicamente constante dentro de uma larga faixa de freqüência (WILLIAMS,1983). A tabela 1, mostra a impedância acústica característica de diversos meios, assim como suas densidades e as velocidades da onda ultra-sônica nestes meios.

TABELA 1 - Propriedades acústicas típicas de vários meios (YOUNG, 1990)

\begin{tabular}{llll}
\hline MEIO & $\begin{array}{l}\text { DENSIDADE } \\
(\mathrm{g} / \mathrm{ml})\end{array}$ & $\begin{array}{l}\text { VELOCIDADE } \\
\text { DO SOM }(\mathrm{m} / \mathrm{s})\end{array}$ & $\begin{array}{l}\text { IMPEDÂNCIA } \\
\text { CARACTERÍSTICA } \\
\left(10^{6} \mathrm{~kg}^{-2} \mathrm{~ms}^{-1}\right)\end{array}$ \\
\hline Ar & 1.293 & 331.5 & 429 \\
Água $\left(20^{\circ}\right)$ & 1.0 & 1480 & 1.52 \\
Plasma sanguíneo & 1.06 & 1570 & 1.62 \\
Gordura & 0.92 & $1460-1470$ & 1.35 \\
Fígado & 1.06 & $1540-1585$ & $1.63-1.68$ \\
Músculo & 1.07 & $1545-1630$ & $1.65-1.74$ \\
Osso & $1.38-1.81$ & $2710-4080$ & $3.75-7.38$ \\
\hline
\end{tabular}




\subsubsection{Reflexão e Refração}

Quando uma onda sonora encontra uma interface entre dois meios diferentes, parte da energia é refletida e outra é refratada. A onda refletida retorna em direção negativa através do meio incidentes com a mesma velocidade de propagação e a onda refratada continua em direção positiva, mas sua velocidade é alterada em função das características do meio (WELLS, 1977).

Como o coeficiente de reflexão $\left(\alpha_{\mathrm{r}}\right)$ e o coeficiente de refração $\left(\alpha_{\mathrm{t}}\right)$ para as ondas incidentes perpendiculares dependem exclusivamente das impedâncias acústicas dos meios (FREDERICK, 1965) e as impedâncias acústicas características dos meios abordados possuem valores muito próximos, ou seja, a impedância característica do gel (água) está ao redor de $1,61 \times 10^{-6} \mathrm{~kg} \cdot \mathrm{m}^{-2} \mathrm{~s}^{-1}$ e dos tecidos moles do corpo está ao redor de $1,62 \times 10^{-6} \mathrm{~kg} . \mathrm{m}^{-2} \mathrm{~s}^{-1}$ (YOUNG,1990). Os valores destes coeficientes são portanto muito próximos e os fenômenos de reflexão e refração foram desconsiderados.

A porcentagem de energia refletida $\left(\alpha_{\mathrm{r}}=\mathrm{Ir} / \mathrm{I}_{\mathrm{i}}\right)$ e transmitida ou refratada $\left(\alpha_{t}=I_{t} / I_{i}\right)$ é obtida através das equações 1 e 2 , sendo $I_{i}, I_{r}$, e $I_{t}$ as intensidades incidente, refletida e transmitida, respectivamente. Os ângulos de incidência e transmissão são $\theta_{\mathrm{i}}$ e $\theta_{\mathrm{t}}$, respectivamente.

$$
\begin{aligned}
& \frac{\mathrm{I}_{\mathrm{r}}}{\mathrm{I}_{\mathrm{i}}}=\left(\frac{\mathrm{Z}_{2} \cos \theta_{i}-Z_{1} \cos \theta_{t}}{Z_{2} \cos \theta_{i}+Z_{1} \cos \theta_{t}}\right)^{2} \\
& \frac{\mathrm{I}_{\mathrm{t}}}{\mathrm{I}_{\mathrm{i}}}=\frac{4 \mathrm{Z}_{2} \mathrm{Z}_{1} \cos \theta_{\mathrm{i}} \cos \theta_{\mathrm{t}}}{\left(\mathrm{Z}_{2} \cos \theta_{\mathrm{i}}+\mathrm{Z}_{1} \cos \theta_{\mathrm{t}}\right)^{2}}
\end{aligned}
$$


Se a incidência for perpendicular ao meio 2 , isto é $\theta_{\mathrm{I}}=90^{\circ}$, as equações 1 e 2 são simplificadas:

$$
\frac{I_{r}}{I_{i}}=\left(\frac{Z_{2}-Z_{1}}{Z_{2}+Z_{1}}\right)^{2}
$$

$$
\frac{I_{r}}{I_{i}}=\frac{4 Z_{2} Z_{1}}{\left(Z_{2}+Z_{1}\right)^{2}}
$$

É possível obter total transmissão da energia acústica entre dois meios 1 e 3 se entre eles for utilizado um meio 2 com impedância acústica $Z_{2}$ dada pela equação (5).

$$
\mathrm{Z}_{2}=\sqrt{\mathrm{Z}_{1} \mathrm{Z}_{3}}
$$

O uso do meio 2 com a finalidade acima é denominada de casamento de impedância e é utilizada na construção de transdutores ultra-sônicos.

\subsubsection{Interferências e Ondas Estacionárias}

As ondas ultra-sônicas podem apresentar um fenômeno exclusivo dos movimentos ondulatórios denominado interferência. A interferência corresponde à 
combinação de duas ou mais ondas em um ponto do meio onde se propagam, podendo ser construtiva ou autodestrutiva.

A interferência construtiva ocorre com a superposição de ventre de ondas que se somam formando um ventre com maior amplitude. A interferência autodestrutiva ocorre com a superposição de ondas com sinais invertidos, tendendo portanto a se anularem.

Essas interferências ocorrem, por exemplo, quando há reflexão de ondas com a formação de ondas estacionárias. Ondas estacionárias são ondas que refletidas ficam confinadas a um determinado espaço e que se ao se sobreporem podem se anular ou se somar (WELLS, 1977).

Como a intensidade é proporcional ao quadrado da amplitude, deve-se procurar evitar a formação de ondas estacionárias, pois a formação de ondas construtivas pode elevar muito a amplitude e danificar os tecidos irradiados. No entanto, na geometria complexa dos tecidos humanos, a ocorrência de ondas estacionárias é pouco provável (TER HAAR in REPACHOLI, 1987).

\subsubsection{Mecanismos de atenuação}

A atenuação corresponde ao decréscimo da intensidade em função da distância da fonte sonora, e ocorre devido a fatores geométricos (dimensões da fonte sonora, comprimento de onda, presença de superfícies refletoras, etc.) e por mecanismos de absorção (viscosidade, tempo de relaxação, etc.). Estes mecanismos possuem características diferentes de acordo com o meio. Nos tecidos biológicos a atenuação deve-se principalmente aos mecanismos de absorção - mecanismos pelos quais a energia mecânica das ondas ultra-sônicas é convertida em calor (TER HAAR, 1978). 
O coeficiente de absorção $(\alpha)$ é diretamente proporcional à freqüência, quanto maior a frequiência, mais rápida é a absorção (TER HAAR, 1987).

A Tabela 2 mostra o coeficiente de absorção para a freqüência de $1 \mathrm{MHz}$ em diferentes meios:

TABELA 2 - Coeficiente de absorção $(\alpha)$ em diferentes tecidos para a freqüência de $1 \mathrm{Mhz}$ (WELL, 1977)

\begin{tabular}{lc}
\hline Tecidos & Coeficiente de absorção $(\boldsymbol{\alpha})$ \\
\hline Sangue & 0.18 \\
Gordura & 0.63 \\
Cérebro & 0.85 \\
Fígado & 0.94 \\
Rim & 1.0 \\
Músculos (paralelo às fibras) & 1.3 \\
Músculos (transversal às fibras) & 3.3 \\
Miocárdio & 1.8 \\
Ossos do crânio & 20 \\
Pulmão & 41 \\
\hline
\end{tabular}

\subsubsection{Transdutores}

O ultra-som de uso médico, fisioterapêutico e odontológico é produzido por transdutores ultra-sônicos. Transdutores são dispositivos com a capacidade de responder a uma tensão elétrica, deformando-se, ou a uma tensão mecânica, alterando sua polarização. Este fenômeno, denominado, piezoeletricidade, foi descoberto por Pierre e Jacques Curie em 1880. Hoje se sabe que a piezoeletricidade é uma propriedade natural de certos cristais e substâncias cristalizadas que 
apresentam anisotropia, ou seja, a capacidade de reagir diferentemente de acordo com a direção de propagação de um fenômeno físico sobre si, como a luz, o calor, etc. (RICHARDSON, 1989).

Alguns cristais naturais como o quartzo e a turmalina são piezoelétricos podendo ser usados como transdutores. No entanto, alguns transdutores podem ser produzidos artificialmente como o titanato de bário $\left(\mathrm{BaTiO}_{3}\right)$ e o zirconato titanato de chumbo (PZT), por exemplo.

Neste trabalho o elemento piezoelétrico usado como transdutor para produção de ondas ultra-sônicas foi um disco circular de zirconato titanato de chumbo (PZT) de $22 \mathrm{~mm}$ de diâmetro e freqüência de ressonância de $1.5 \mathrm{MHz}$.

\subsection{Mecanismos de interação do ultra-som com células e tecidos biológicos}

Os efeitos biológicos da ação do ultra-som dependem de muitos fatores físicos e biológicos, tais como intensidade, tempo de exposição, estrutura espacial e temporal do campo ultra-sônico e estado fisiológico do objeto. Este grande número de variáveis complica a compreensão exata do mecanismo de ação do ultra-som na interação com os tecidos biológicos (SARVAZYAN, 1983).

Experimentos realizados com o ultra-som demonstram que a interação deste com os tecidos biológicos provoca alterações fisiológicas, que podem ser benéficas ou provocar danos.

Independente do tipo de mecanismo de interação que está agindo no tecido biológico estudado, o objetivo principal tem sido estabelecer limiares para a intensidade ultra-sônica, abaixo dos quais não ocorrem efeitos lesivos (FERRARI, 1987). 
HILL (1972) considerou o limiar de $100 \mathrm{~mW} / \mathrm{cm}^{2}$ de intensidade como não lesivo para os tecidos biológicos, com referência especial à desnaturação do colágeno.

Os mecanismos físicos envolvidos na terapêutica do ultra-som que induzem respostas clinicamente significantes sobre as células, tecidos, órgãos e organismos são geralmente classificados em mecanismos térmicos e não-térmicos (DYSON, 1987).

Esses mecanismos e seus subseqüentes efeitos estão diretamente relacionados com os parâmetros físicos do ultra-som, com o tempo e a técnica de aplicação.

\subsubsection{Mecanismo térmico}

Quando uma onda ultra-sônica atravessa um tecido biológico, este é aquecido ao absorver parte da energia mecânica ultra-sônica. $\mathrm{O}$ aumento da temperatura provoca um aumento temporário na extensibilidade das estruturas altamente colagenosas, como os tendões, ligamentos e cápsulas articulares, e uma redução na dor e espasmos musculares além de produzir uma reação inflamatória branda.

O aquecimento local produzido pelo ultra-som depende do tipo de tecido (os tecidos altamente protéicos absorvem energia mais prontamente do que os tecidos com alto teor de gordura), do fluxo sangüíneo que irriga o local (uma vez que o calor produzido pode ser dissipado por corrente sanguínea) e da freqüência ultra-sônica aplicada (as altas freqüências têm uma maior absorção) (DYSON, 1987). 
Estudos indicam que as altas freqüências são lesivas e podem danificar tecidos e células quando a intensidade utilizada ultrapassa o limiar de $100 \mathrm{~mW} / \mathrm{cm}^{2}$ (HILL, 1972).

A elevação da temperatura tecidual produzida através da absorção da energia ultra-sônica pode trazer benefícios através de uma vasodilatação local ou até queimar os tecidos irradiados.

$\mathrm{O}$ aumento da temperatura em um tecido irradiado com ultra-som é determinado por diferentes fatores, dos quais os mais importantes são:

O coeficiente de absorção do tecido;

A taxa de energia ultra-sônica depositada, a qual depende da intensidade ultra-sônica, da distribuição de energia no campo e do modo de propagação da onda;

A freqüência da onda ultra-sônica;

O tempo de irradiação local;

A técnica de aplicação: estacionária ou móvel;

As dimensões do corpo aquecido;

A presença ou ausência de superfícies refletoras na frente ou atrás do tecido de interesse (WILLIAMS, 1983).

Com os parâmetros do feixe ultra-sônico otimizados para o uso terapêutico em tecidos superficiais (média e baixas intensidades e altas frequiências), o aumento local da temperatura e da ordem de centésimos de grau até pouco mais de $1^{\circ} \mathrm{C}$ (DYSON \& SUCKLING, 1978). 


\subsubsection{Mecanismos não-térmicos}

Com a constatação dos efeitos lesivos provocados pelas altas intensidades, muitos autores têm utilizado intensidades acústicas mais baixas na estimulação ultra-sônica. Estas intensidades são muito baixas para provocarem um aumento significativo na temperatura, fato que indica que outros mecanismos que não os térmicos estão envolvidos na interação do ultra-som com o tecido biológico (DYSON, 1987). Dentre os mecanismos não-térmicos que produzem efeitos nos tecidos biológicos podemos citar o mecanismo cavitacional.

\subsubsection{Cavitação}

Cavitação é o termo usado em geral para descrever as atividades de microbolhas em um meio contendo líquido (sangue ou em fluidos dos tecidos), quando estimulado acusticamente. A cavitação engloba formação, crescimento, colapso e efeitos (físicos, químicos e biológicos) associados às bolhas gasosas (FRIZZEL \& DUNN, 1984).

Essas bolhas de gás formadas no tecido biológico com a passagem de ondas ultra-sônicas, podem permanecer intactas por muitos ciclos (cavitação estável) ou entrar em colapso liberando grande quantidade de energia (cavitação transiente) (WELLS, 1977).

Não existem evidências que ocorram efeitos danosos de cavitação in vivo em tecidos tratados com ultra-som de baixa intensidade (DYSON, 1990). 


\subsection{Cavitação transiente}

Quando o feixe ultra-sônico atravessa o campo oscilando violentamente, provocando grandes alterações no volume das bolhas levando-as ao colapso, o que pode determinar também a implosão celular, denomina-se cavitação transiente (TER HAAR, 1987). A cavitação transiente é extremamente danosa. As alterações de pressão e temperatura produzidas no sítio do colapso das bolhas podem desintegrar o tecido local com formação de radicais livres altamente reativos que podem causar mudanças químicas nas células e lise celular (OKUNO, CALDAS \& CHOW, 1986).

No entanto, a cavitação transiente requer intensidades muito mais altas do que aquelas usadas terapeuticamente (aproximadamente $10 \mathrm{w} / \mathrm{cm}^{2}$ ) (LEITE, 1989), desta forma sua ocorrência em tecidos biológicos é bastante improvável.

\section{3.2.1.2 Cavitação estável}

Quando as bolhas atravessam o campo ultra-sônico oscilando em um feixe estável, aumentando e diminuindo seu volume conforme as variações de pressão de campo, dizemos que a cavitação é estável (TER HAAR, 1987). Este tipo de cavitação é responsável, em parte, pela estimulação do reparo de tecidos que a onda ultra-sônica produz, através de modificações na permeabilidade da membrana celular para os íons de cálcio (MUMMERY apud YOUNG \& DYSON, 1978) e sódio (MORTIMER \& DYSON, 1988) que provocam um aumento na síntese de proteínas.

Há evidências experimentais consideráveis de que níveis terapêuticos de ultra-som podem induzir a cavitação estável "in vivo" (TER HAAR,1982), mas seus efeitos ainda não estão bem estabelecidos. Entretanto, sabe-se que a cavitação estável 
“in vitro" pode produzir efeitos irreversíveis em suspensão celular, como a ruptura de membranas e de macromoléculas, a desnaturação de enzimas, etc., dependendo dos parâmetros usados (LEITE,1989).

A intensidade limiar a partir do qual pode ocorrer cavitação foi determinada em meio aquoso por HILL (1971) em $0,1 \mathrm{~W} / \mathrm{cm}^{2}$, e "in vivo" por TER HAAR et al. (1982) em $0,2 \mathrm{~W} / \mathrm{cm}^{2}$.

\subsubsection{Fluxo e Microfluxo}

Fluxo (streaming) e microfluxo (microstreaming) correspondem a movimentos unidirecionais que ocorrem em fluidos submetidos a um campo ultrasônico. Esses movimentos originam forças e tensões que podem modificar a posição de partículas intra e extra-celulares ou mesmo a configuração normal das células, e consequentemente podem afetar a atividade celular (OKUNO, CALDAS \& CHOW, 1986).

Podem alterar organelas celulares e membranas de maneira reversível ou irreversível, dependendo de sua magnitude. O microfluxo pode ter seu valor terapêutico uma vez que sua ação facilita a difusão através de membranas. Dependendo do tipo de célula, a alteração iônica produzida pode desenvolver alterações na motilidade, síntese ou secreção celular, que podem acelerar o processo de reparo (DYSON, 1987).

Diversos experimentos têm sugerido que o microfluxo causado em tecidos submetidos a níveis terapêuticos de ultra-som é um dos mecanismos responsáveis pela regeneração de tecidos lesados (HADAAD, 1992). 


\subsubsection{Piezoeletricidade}

A piezoeletricidade foi descoberta em 1880 pelos irmãos Curie (MASON, 1981) e é definida como a propriedade física segundo a qual alguns materiais quando deformados por uma tensão mecânica, desenvolvem cargas elétricas superficiais e vice-versa, i. e., ao se colocar um material piezoelétrico sob campo elétrico, as cargas elétricas interagem com o mesmo e o material exibe deformações mecânicas (OKUNO, CALDAS \& CHOW, 1986).

FUKADA \& YASUDA (1957) foram os primeiros a descreverem a piezoeletricidade em um tecido biológico - o osso. Eles observaram os efeitos direto e inverso no osso, e mostraram que ao sofrer deformações mecânicas, cargas elétricas são formadas na face oposta do osso, sendo este efeito devido à molécula de colágeno.

A piezoeletricidade continuou a despertar o interesse da comunidade científica, que procurou estabelecer uma relação entre eletricidade e os mecanismos de crescimento e regeneração.

As pesquisas de aplicação com energia ultra-sônica pulsada de baixa intensidade tiveram em nosso país e na América Latina como pioneiro o Prof. Luiz Romariz Duarte e sua equipe da Escola de Engenharia de São Carlos - USP e seus estudos demonstraram evidências de que o ultra-som pode acelerar o reparo ósseo. Atribuiu a aceleração do processo de consolidação de fraturas ósseas por ultra-som de baixa intensidade ao mecanismo de piezoeletricidade (DUARTE, 1983).

XAVIER e DUARTE (1983) relatam o impacto que a descoberta da piezoeletricidade em tecido ósseo por Fukuda teve no desenvolvimento de técnicas não-invasivas de tratamento de fraturas. A intervenção do homem resume-se, pois, em como "colocar" cargas elétricas no sítio lesado ou como estabelecer uma corrente elétrica que produza ativação naquele ambiente. No caso do ultra-som, as cargas elétricas necessárias ao reparo ósseo são produzidas no osso por meio do efeito 
piezoelétrico, pois o USP atinge a superfície do osso por uma sucessão de impulsos, cada um deles resultando em um sinal elétrico como resposta do osso. Daí por diante, o processo de crescimento do osso regulado pelo campo elétrico assim formado e o metabolismo ósseo é estimulado bioeletricamente tal como nos outros métodos invasivos ou não de tratamento de fraturas.

A piezoeletricidade (definida no item 2.2.7) é um dos principais mecanismos a que se atribui os efeitos ultra-sônicos produzidos na reparação do tecido ósseo.

Este mecanismo se deve à propriedade piezoelétrica da molécula de colágeno. Supõe-se que a energia mecânica das ondas seja convertida em energia elétrica pelas unidades de tropocolágeno, criando assim um campo elétrico na superfície do osso fraturado, o que estimularia a proliferação de células ósseas (XAVIER \& DUARTE, 1983).

SILVA (1987) demonstrou teoricamente que a aplicação de um campo acústico em tecido ósseo produz um campo elétrico ao nível da membrana celular e pressupõe que este efeito deve ocorrer em todos os tecidos que contém colágeno, o que pode ser um dos mecanismos para o efeito do ultra-som sobre o osso e a pele. 


\section{TECIDO MUSCULAR}

Segundo JUNQUEIRA \& CARNEIRO (1999), o tecido muscular, responsável pelos movimentos corporais, é constituído por células alongadas e que contém grande quantidade de filamentos citoplasmáticos, responsáveis pela contração.

São denominadas estriadas ou lisas dependendo, respectivamente, da presença ou ausência de um arranjo de proteínas contráteis miofibrilares, os miofilamentos, que se repetem regularmente (GARTNER \& HIATT, 1997).

A diferenciação das células musculares, de origem mesodérmica, ocorre principalmente devido a um processo de alongamento gradativo e, com simultânea síntese destas proteínas filamentosas.

\subsection{Características morfológicas e funcionais do músculo}

Pode-se distinguir nos mamíferos três tipos de tecido muscular: o músculo liso, o músculo estriado cardíaco e o músculo estriado esquelético (objeto deste estudo), observando suas características morfológicas e funcionais (Figura 5). 
As células musculares estriadas, cardíacas e esqueléticas, apresentam estriações características, claras e escuras, que estão ausentes no músculo liso (GARTNER \& HIATT, 1997).

O músculo estriado esquelético, responsável pela maior parte da massa muscular voluntária do corpo, é formado por feixes de células cilíndricas muito longas e multinucleadas, que apresentam estriações transversais. Tem contração rápida, vigorosa e sujeita ao controle voluntário. O músculo estriado cardíaco, é involuntário e limitado quase exclusivamente ao coração. Apresenta estrias transversais, é formado por células alongadas e ramificadas, que se unem por intermédio dos discos intercalares, estruturas encontradas exclusivamente no músculo cardíaco. Apresentam contração involuntária, vigorosa e rítmica. O músculo liso está localizado nas paredes dos vasos sangüíneos e nas vísceras, bem como na derme. É formado por aglomerados de células fusiformes que não possuem estrias transversais. O processo de contração é lento e não está sujeito ao controle voluntário (GARTNER \& HIATT, 1997; JUNQUEIRA \& CARNEIRO, 1999).

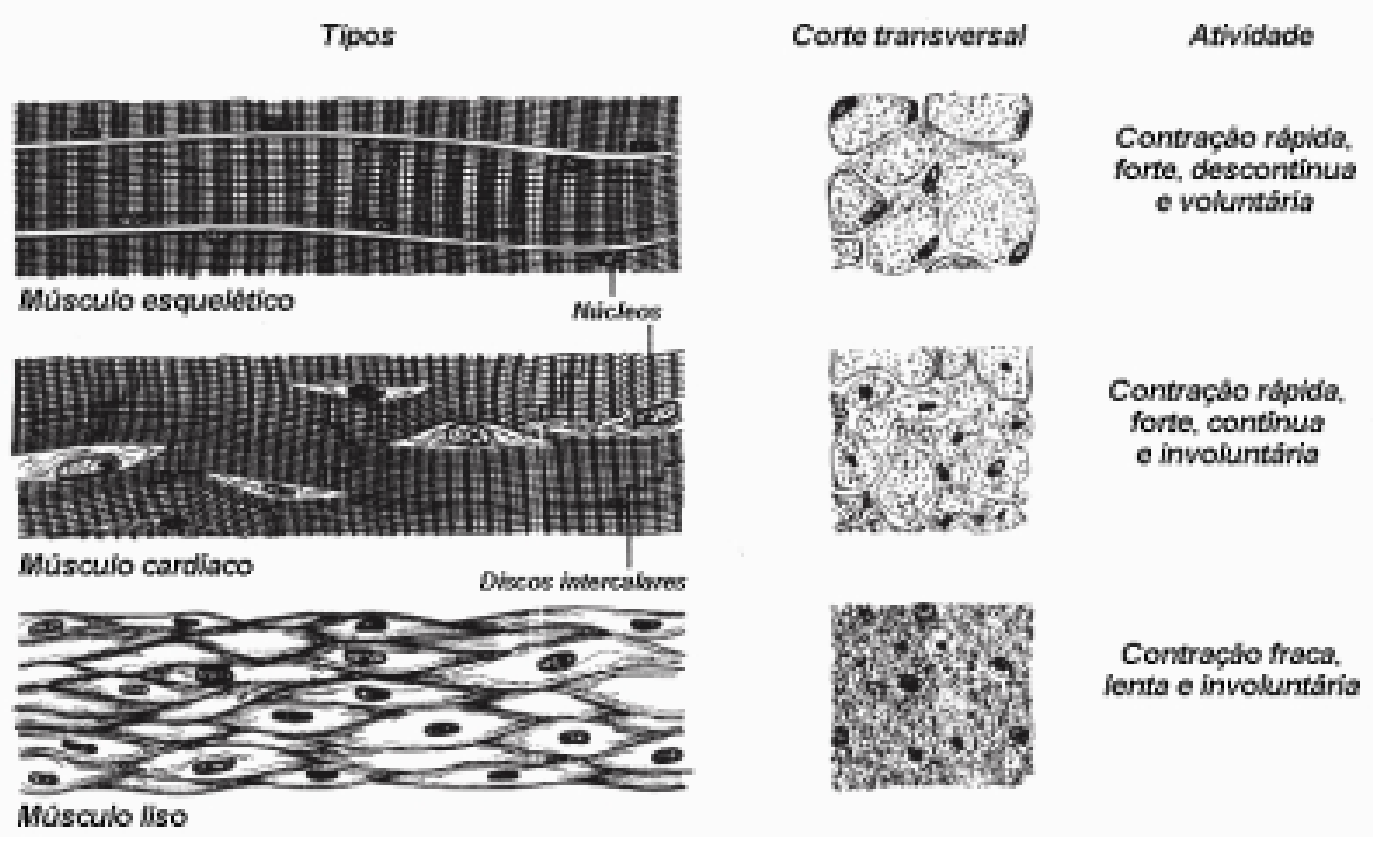

FIGURA 5 - Tipos de músculos (Junqueira \& Carneiro, 1999, p. 159). 


\subsection{O músculo estriado esquelético}

Termos próprios são freqüentemente utilizados na descrição dos componentes das células musculares. Assim, a membrana celular é chamada sarcolema; o citoplasma, sarcoplasma; o retículo endoplasmático liso, retículo sarcoplasmático; e, ocasionalmente, as mitocôndrias, sarcossomas. Em razão de seu comprimento ser maior que sua largura, as células musculares são, freqüentemente, chamadas de fibras musculares (GARTNER \& HIATT, 1997) .

Estas fibras são dispostas paralelamente em relação às vizinhas. Tem vários núcleos, e estão situados na periferia da célula, sob a membrana celular (sarcolema). Os elementos contráteis ocupam a maior parte do volume da célula, que tem uma relação muita ordenada e específica entre si, organização essa responsável pelas estriações transversais vista nos cortes longitudinais das fibras musculares esqueléticas e que deram origem à denominação de músculo estriado. O músculo esquelético é fartamente irrigado com sangue e, geralmente, cada fibra tem em suas proximidades vários capilares (ROSS \& ROWRELL, 1993). Os vasos sangüíneos penetram no músculo através dos septos do tecido conjuntivo e formam uma rica rede de capilares que correm entre as fibras musculares (JUNQUEIRA \& CARNEIRO, 1999).

As fibras musculares estriadas têm até $30 \mathrm{~cm}$, com um diâmetro que varia de 10 a $100 \mu \mathrm{m}$. Originam-se no embrião através da fusão de células alongadas, os mioblastos (Figura 5) (JUNQUEIRA \& CARNEIRO, 1999; WILLIAMS et al., 1995). 


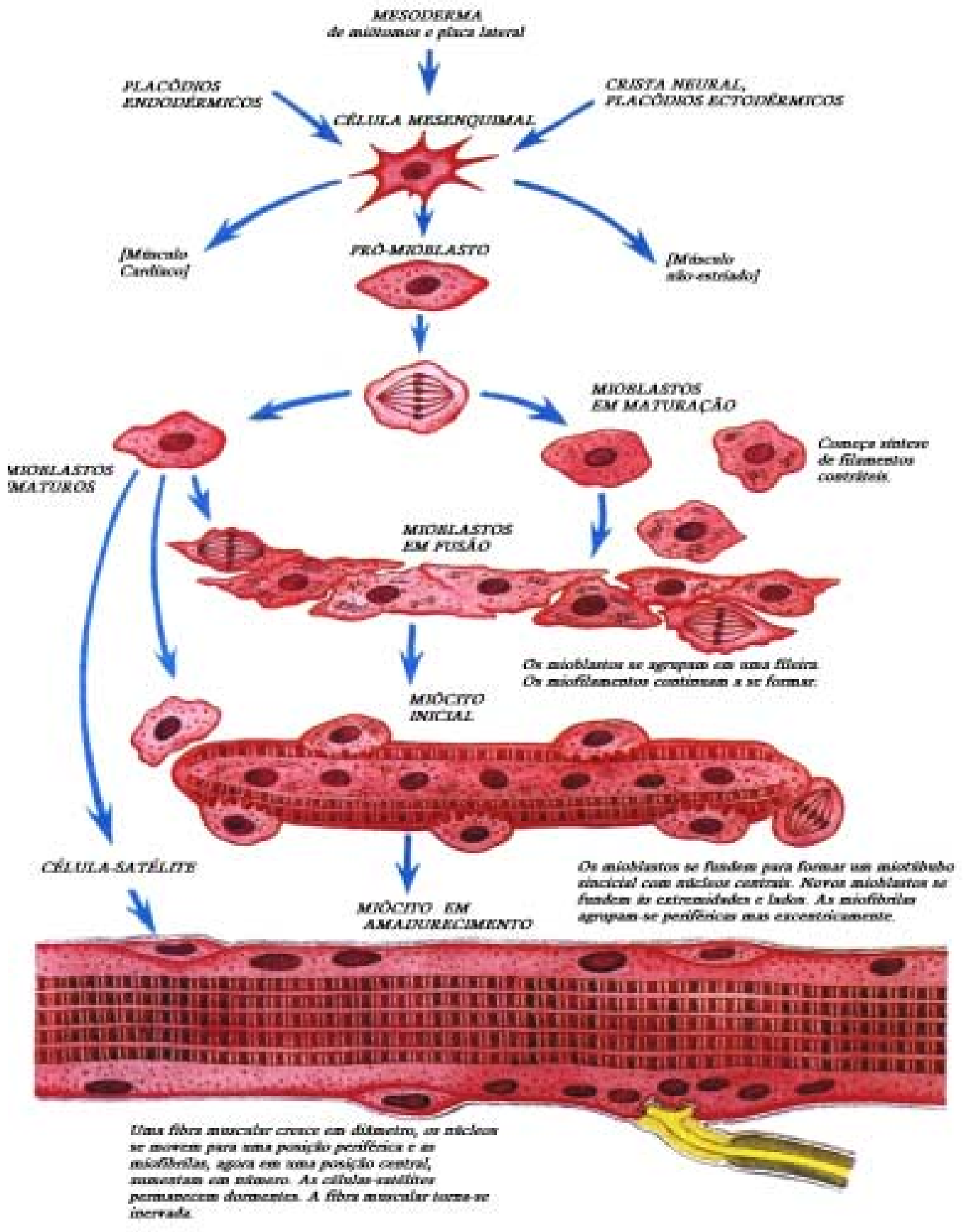

FIGURA 6 - Esquema ilustrativo da origem embriológica de uma fibra muscular esquelética (WILLIAMS et a1., 1995). 
Muitas centenas de mioblastos, alinham-se com as extremidades voltadas umas para outras, fundem-se e formam células longas, conhecidas como miotubos. Segundo MALTIN et al. (1983), miotubo é um sincício (célula que foi gerada pela fusão de duas ou mais células, através do desaparecimento das paredes de células contíguas) no qual os núcleos são normalmente arranjados em uma cadeia central. Usualmente contém uma população de miofibrilas limitada, amplamente espaçadas.

Estes miotubos recém-formados produzem os constituintes citoplasmáticos, bem como elementos contráteis, chamados miofibrilas. As miofibrilas são formadas pelo arranjo específico de miofilamentos, que são proteínas responsáveis pela capacidade contrátil das células.

Num músculo, as fibras musculares estão organizadas em grupos de feixes (fascículos) envolvidos por uma camada de tecido conjuntivo, chamado epimísio. Do epimísio partem septos muito finos de tecido conjuntivo, que se dirigem para o interior do músculo, separando os feixes. Esses septos são chamados de perimísio. O perimísio envolve cada feixe de fibras musculares. Cada fibra muscular, por sua vez, é envolvida por uma camada muito fina constituída pela lâmina basal da fibra muscular e por fibras reticulares do endomísio (Figura 7).

A função deste tecido conjuntivo é manter as fibras musculares unidas, permitindo que a força de contração gerada por cada fibra individualmente atue sobre o músculo inteiro (grande significado funcional) porque na maioria das vezes as fibras não se estendem de uma extremidade até a outra do músculo. 


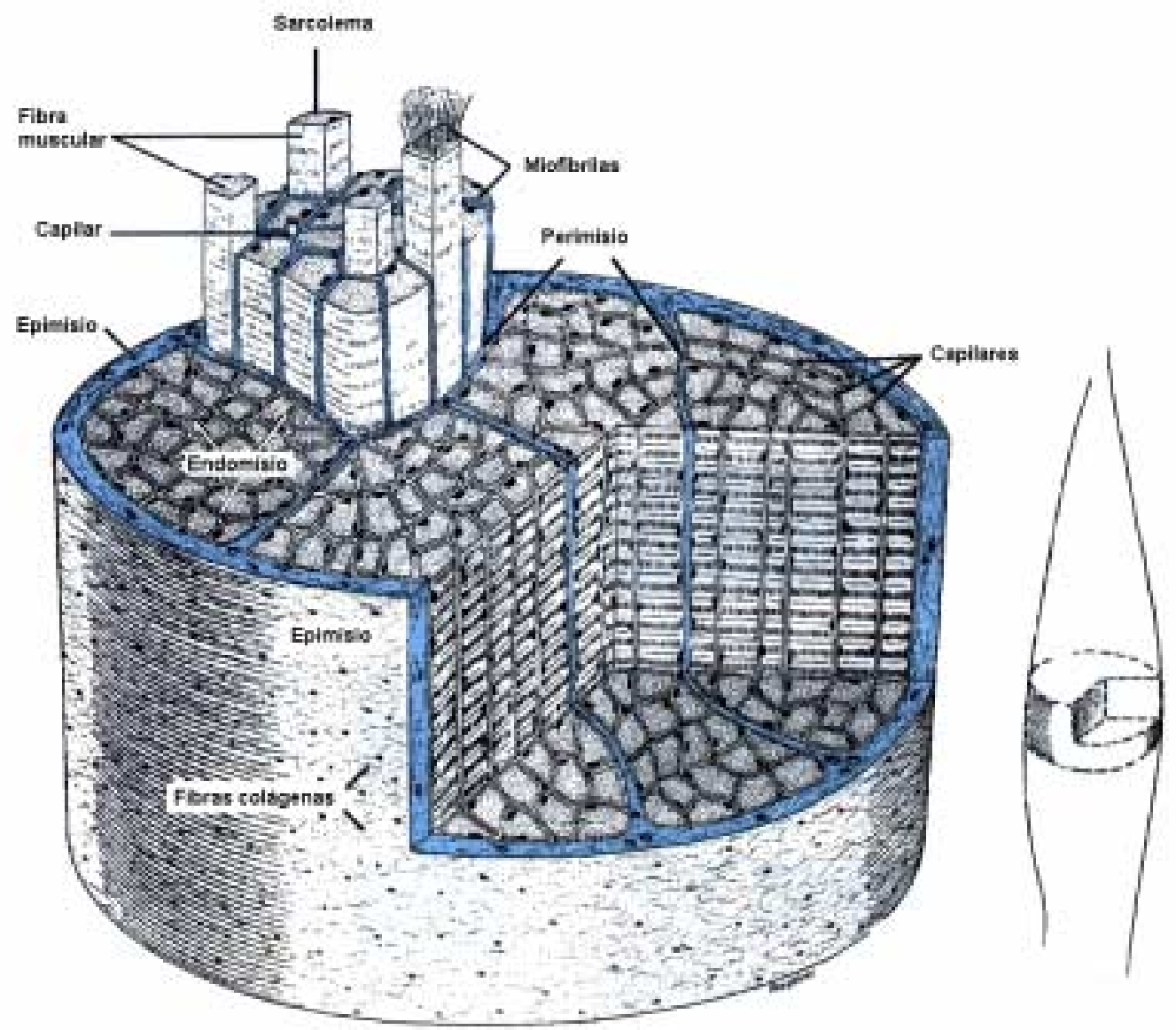

FIGURA 7 - Esquema ilustrativo da arquitetura de um músculo esquelético segundo JUNQUEIRA \& CARNEIRO, 1999.

O citoplasma da fibra muscular apresenta-se preenchido, quase completamente, principalmente por fibrilas paralelas, as miofibrilas (cilíndricas, com um diâmetro de $1 \mathrm{a} 2 \mu \mathrm{m}$ ). Aparecem com estriações transversais, pela alternância de faixas claras e escuras. A faixa escura (anisotrópica) recebeu o nome de banda A, enquanto a faixa clara (isotrópica) banda I. No centro de cada banda I aparece uma linha transversal escura - a linha $\mathrm{Z}$.

A estriação da miofibrila é devida à repetição de unidades iguais, chamadas sarcômeros. Cada sarcômero é formado pela parte da miofibrila que fica entre as duas linhas $\mathrm{Z}$ sucessivas e contém uma banda $\mathrm{A}$ separando duas semibandas I. 
A banda A apresenta uma zona mais clara no seu centro, a banda H. A disposição dos sarcômeros coincide nas várias miofibrilas da fibra muscular, e as bandas formam um sistema de estriações transversais, paralelas, que é característico das fibras musculares estriadas.

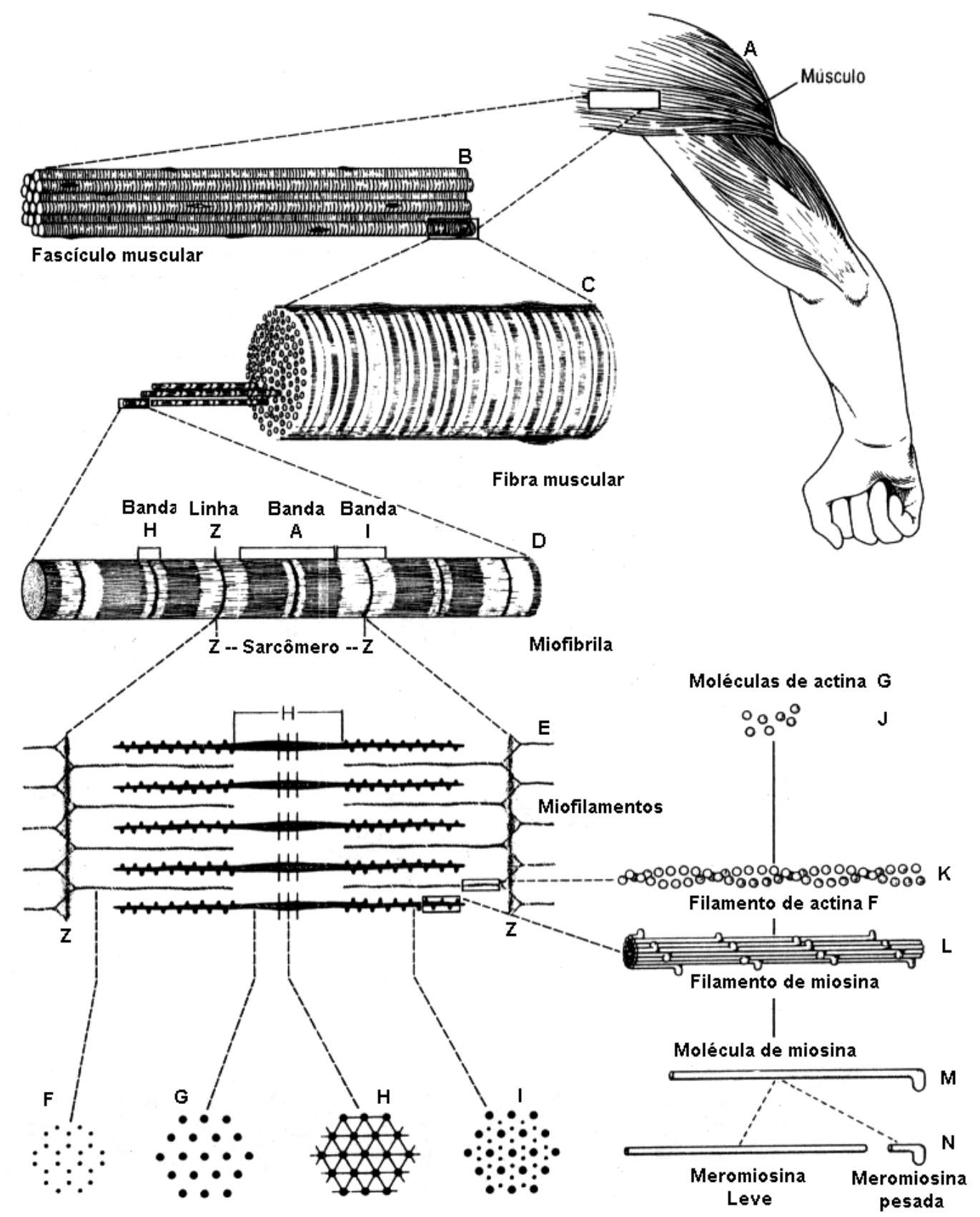

FIGURA 8 - Esquema ilustrativo de um sarcômero e seus componentes, segundo JUNQUEIRA \& CARNEIRO, 1999. 
O microscópio eletrônico revela a presença de filamentos finos de actina e filamentos grossos de miosina dispostos longitudinalmente nas miofibrilas e organizados numa distribuição simétrica e paralela (Figura 8). Na contração muscular os filamentos de actina deslizam sobre os filamentos de miosina. A miosina e a actina representam $55 \%$ do total de proteínas do músculo estriado.

Essa organização dos filamentos miofibrilares é mantida por diversas proteínas, como por exemplo filamentos intermediários de desmina, que ligam as miofibrilas umas às outras. O conjunto de miofibrilas (actina e miosina) é, por sua vez, preso à membrana plasmática da célula muscular por meio de diversas proteínas que tem afinidade pelos miofilamentos e por proteínas da membrana plasmática. Uma dessas proteínas, chamada distrofina, liga os filamentos de actina a proteínas integrais da membrana plasmática.

A contração normal das fibras musculares esqueléticas é comandada por nervos motores que se ramificam no tecido conjuntivo do perimísio, onde cada nervo origina numerosas terminações. No local de inervação, o nervo perde sua bainha de mielina e forma uma dilatação que se coloca dentro de uma depressão da superfície da fibra muscular. Esta estrutura chama-se placa motora.

A despolarização iniciada na placa motora propaga-se ao longo da membrana da fibra muscular e penetra na profundidade da fibra através do sistema de túbulos transversais. Em cada tríade, estrutura tripla vista no corte transversal, onde as duas cisternas terminais ladeiam um túbulo transversal na junção A-I, o sinal despolarizador passa para o retículo sarcoplasmático e resulta na liberação de $\mathrm{Ca}^{2+}$, que inicia o ciclo de contração. Quando a despolarização termina, o $\mathrm{Ca}^{2+}$ é transportado ativamente de volta para as cisternas do retículo sarcoplasmático e o músculo relaxa (ROSS \& ROWRELL, 1993; JUNQUEIRA \& CARNEIRO, 1999).

Uma fibra nervosa pode inervar uma única fibra muscular ou então se ramificar e inervar até 160 ou mais fibras musculares. A fibra nervosa e as fibras musculares por ela inervadas formam uma unidade motora. 
A cor do músculo esquelético vai do róseo ao vermelho, por causa do rico suprimento vascular, bem como da presença de pigmentos de mioglobina, que são proteínas transportadoras de oxigênio, semelhantes à hemoglobina, mas que são menores do que esta. Dependendo da quantidade de mioglobina, do número de mitocôndrias, da concentração de várias enzimas e do grau de contração, a fibra muscular pode ser classificada de vermelha (tipo I), branca (tipo II) e intermediária (GARTNER \& HIATT, 1997; JUNQUEIRA \& CARNEIRO, 1999).

As fibras musculares esqueléticas identificadas como do tipo I, ou fibras lentas, são ricas em sarcoplasma, de cor vermelho-escura, adaptadas para contrações continuadas. As fibras do tipo II, ou fibras rápidas, são de cor vermelho-clara, adaptadas para contrações rápidas e descontínuas (JUNQUEIRA \& CARNEIRO, 1999).

Dois importantes processos podem modificar o tecido muscular: hipertrofia (processo caracterizado pelo aumento do volume das células), e hiperplasia (crescimento devido à proliferação das células por multiplicação mitótica) (JUNQUEIRA \& CARNEIRO, 1999).

Quanto à regeneração: no adulto, os três tipos de tecido muscular exibem diferenças na capacidade regenerativa após uma lesão que produza destruição parcial do músculo. O músculo cardíaco não se regenera. Nas lesões do coração, como nos enfartes, por exemplo, as partes destruídas são invadidas por fibroblastos que produzem fibras colágenas, formando uma cicatriz de tecido conjuntivo denso. $\mathrm{O}$ músculo liso é capaz de uma resposta regenerativa eficiente. Ocorrendo lesão, as células musculares lisas que permanecem viáveis entram em mitose e reparam o tecido destruído (JUNQUEIRA \& CARNEIRO, 1999).

Segundo CARLSON apud WILLIAMS et al. (1995), a regeneração do músculo esquelético do homem é limitada, e se a lesão é grande, a regeneração pode não ocorrer, o músculo perdido é então substituído por tecido conectivo.

Embora os núcleos das fibras musculares esqueléticas não se dividam, o músculo tem uma pequena capacidade de reconstituição. Admite-se que as células 
satélites sejam responsáveis pela regeneração do músculo esquelético. A Célula Satélite é uma célula mononucleada situada entre a membrana plasmática e a lâmina basal da fibra muscular (MALTIN et al., 1983). As células satélites são fusiformes, dispostas paralelamente às fibras musculares, dentro da lâmina basal que envolve as fibras e só podem ser identificadas no microscópio eletrônico (JUNQUEIRA \& CARNEIRO, 1999).

Essas células satélites, apresentam núcleos que parecem pertencer à célula muscular, mas que na realidade pertencem a estas pequenas células. Elas localizam-se entre a membrana celular da célula muscular e sua lâmina basal; são células-tronco latentes (são consideradas mioblastos inativos) que podem proliferar após qualquer pequena lesão para dar origem a novos mioblastos. Após uma lesão ou outro estímulo, as células satélites tornam-se ativas, proliferam por divisão mitótica e se fundem umas às outras para formar novas fibras musculares esqueléticas. Enquanto a lâmina basal permanece íntegra, os mioblastos fusionam-se dentro dela para formar miotubos que, quando maduros, originam novas fibras. Em contrapartida, o rompimento da lâmina basal produz o reparo por fibroblastos do local lesado com formação de tecido cicatricial. As células satélites também entram em mitose quando o músculo é submetido a exercício intenso. Neste caso elas se fundem com as fibras musculares preexistentes, contribuindo para a hipertrofia do músculo (JUNQUEIRA \& CARNEIRO, 1999; ROSS \& ROWRELL, 1993). 


\subsection{Visualização das principais estruturas do tecido muscular}

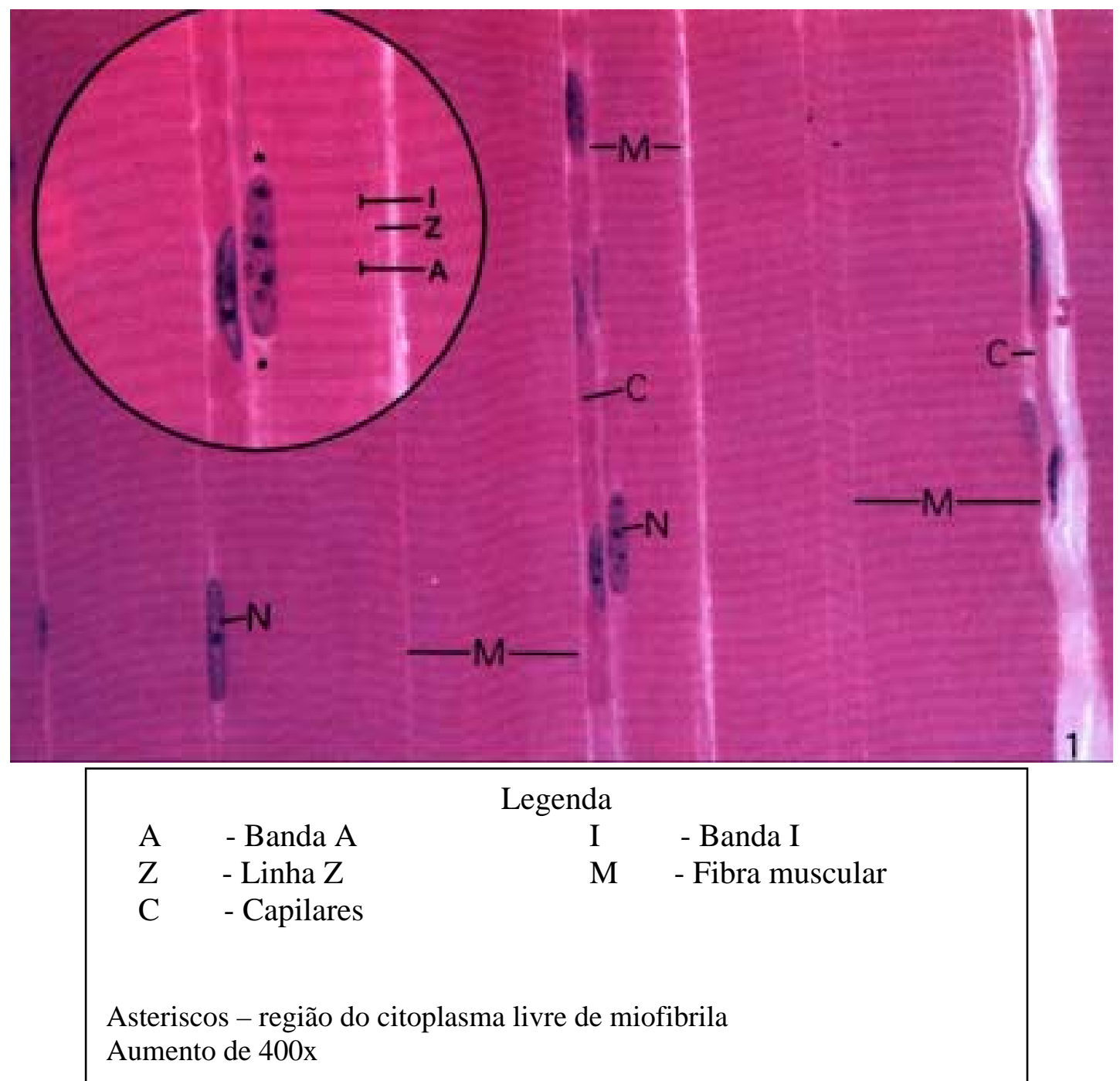

FIGURA 9 - Corte longitudinal de uma fibra de músculo estriado (ROSS \& ROWRELL, 1993).

Neste corte pode-se observar o alinhamento paralelo (M) das fibras musculares; elas estão orientadas verticalmente na ilustração e parecem ter espessuras diferentes. No destaque circular são vistas as estriações. Podem ser visualizadas as bandas A (mais escura) e a banda I (mais clara). Além disso, esse 
destaque mostra uma linha delgada que divide em duas a banda I; trata-se da linha Z. A banda H não é visível.

Ainda no destaque, pode-se examinar o citoplasma em torno do núcleo. Este revela que as estriações transversais não se estendem até as áreas citoplasmáticas adjacentes aos pólos nucleares. Esse citoplasma cora-se ligeiramente (asterisco) e contém uma concentração de organelas que não participam diretamente do processo de contração.

Entre as fibras musculares há uma pequena quantidade de tecido conjuntivo delicado, o endomísio (a letra $\mathrm{C}$ mostra a presença eritrócitos nos capilares situados no endomísio).

Na Figura 10 é possível observar a forma poligonal das fibras quando cortadas transversalmente. Ocorre uma grande variação no que diz respeito à largura de cada fibra incluída no corte, porque algumas podem ser cortadas ao longo do seu diâmetro maior; outras, ao longo do seu diâmetro menor; e outras, ainda, ao longo de diâmetro intermediários.

São parcialmente definidas por numerosos núcleos, mas, no aumento mostrado na Figura 10, não é fácil afirmar se esses núcleos pertencem às células musculares, às células do endotélio capilar, às células satélites ou aos fibroblastos do endomísio, que circunda cada célula muscular. Uma quantidade maior de tecido conjuntivo (CT) separa os feixes de fibras musculares; este tecido conjuntivo é chamado perimísio; contém artérias e veias. 


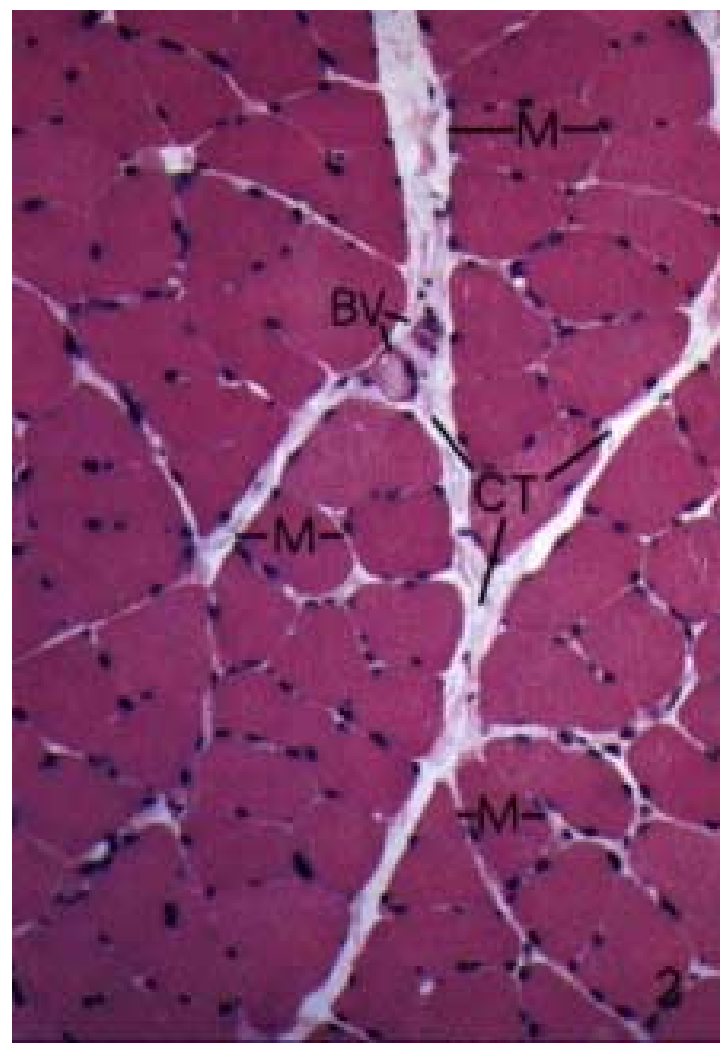

Legenda

BV - Vasos sanguíneos
CT - Tecido conjuntivo
(perimísio)
M - Fibra muscular
$\quad$ (envolvida pelo

FIGURA 10 - Representativo de um corte transversal de fibras musculares estriadas (aumento de 260x) (ROSS \& ROWRELL, 1993).

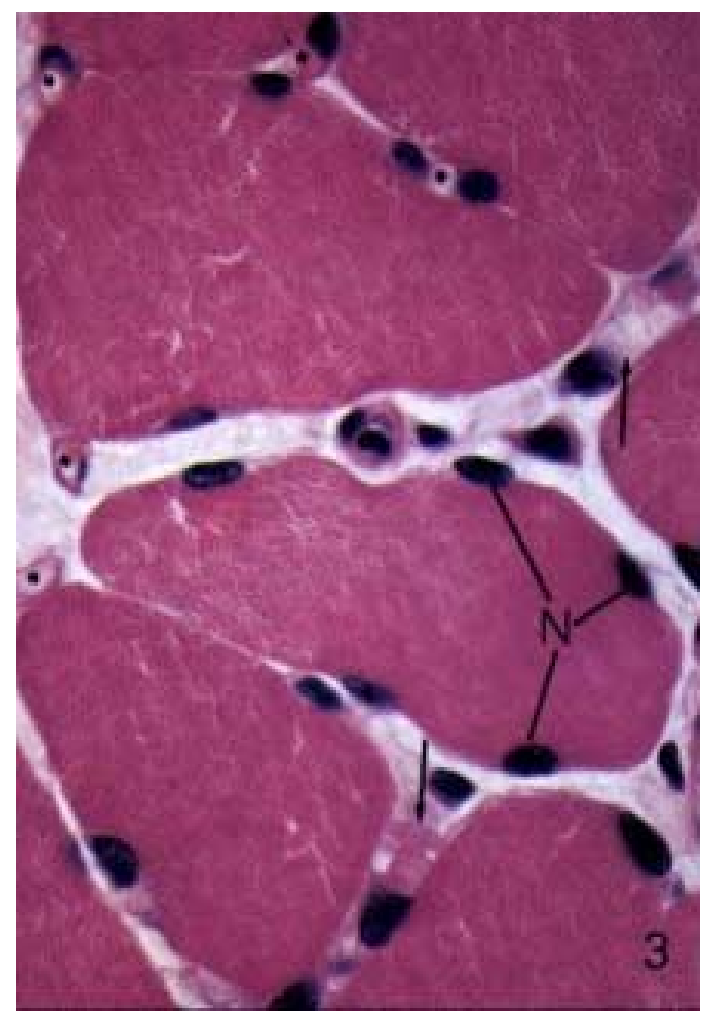

Legenda

$\begin{array}{llll}\mathrm{N} \quad- & \text { Núcleos das células } \\ \text { musculares } & & \end{array}$

Setas - eritrócitos nos capilares

FIGURA 11 - Corte transversal de fibras musculares estriadas (aumento de 640 vezes) (ROSS \& ROWRELL, 1993). 
A Figura 11 mostra várias células musculares, em maior aumento. Os núcleos $(\mathrm{N})$ que se projetam para o interior do citoplasma pertencem à célula muscular (contudo, deve-se observar que alguns núcleos, nessa posição, podem pertencer às células satélites, indiferenciadas, situadas no lado muscular da lâmina basal e que não podem ser identificadas com precisão em amostras coradas com $\mathrm{H}$ \& E). Revelam-se numerosas estruturas anulares (asteriscos) no endomísio; trata-se de capilares "vazios". As setas mostram eritrócitos de capilares que foram cortados mais oblíqua ou longitudinalmente. 


\section{REVISÃO DA LITERATURA}

A regeneração do músculo esquelético sempre foi investigada tendo como padrão alguns dispositivos e artifícios experimentais para a sua investigação, tais como: transplante de músculo; regeneração de enxertos livres; regeneração após denervação ou de músculo inervado; padronização de lesões; injeções de anestésicos ou venenos; exercícios exaustivos; calor; frio; isquemias; incisões; transplantes de fragmentos e auto transplantes.

LAWSON-SMITH \& McGEACHIE (1998), referem que a miogênese e a regeneração celular dependem das células satélites (mpc - células mioprecursoras), as quais seriam as precursoras da miogênese, embora pouco se saiba (a exceção de sua localização anatômica em relação à célula muscular normal ou à sua capacidade de migrar), a respeito do seu papel na miogênese. $\mathrm{O}$ uso da timidina triciada para marcar a proliferação de células satélites (as quais não são distinguíveis no tempo) e a subsequente localização de sua progenie nos núcleos dos miotubos revelaram uma coincidência com o tempo da miogênese, mas não com a natureza das células satélites.

CAMPION (1984) na sua revisão sobre célula satélite muscular (mpc) diz que desde 1961, quando houve a primeira referência às células satélites, sabe-se consideravelmente sobre sua distribuição filogenética, sua localização, morfologia e função. Não há dúvidas que seja capaz de multiplicar-se e ter uma considerável motilidade. Funcionam como progenitoras de núcleos de miofibras e são provavelmente adicionadas durante o crescimento pós-natal do músculo. Quando da 
regeneração muscular funcionam como célula tronco da miogênese para produzir mioblastos que se alinham, usando como suporte as lâminas basais remanescentes, ou migram nos interstícios para produzir uma neofibra.

Os mecanismos mediante os quais um grande número de estímulos ativam as células satélites não são conhecidos e nem aqueles mecanismos que mantém as células satélites inativas durante o crescimento e na idade adulta. Fatores mitogenéticos estão presentes na lesão muscular; suas características específicas e mecanismos de ação são desconhecidos. Maior compreensão desses mecanismos poderia aumentar a possibilidade da recuperação total do músculo submetido a uma lesão ou doença.

CARLSON (1986), considera que entre os modelos experimentais para o estudo da regeneração muscular o ideal seria o transplante de fragmentos musculares. Assim considerando, os três maiores fenômenos ligados à regeneração seriam: a revascularização, a reinervação e o restabelecimento de conexões tendinosas.

No que concerne ao comportamento das células na regeneração do músculo lesado, LEFAUCHER \& SÉBILLE (1995) consideram que este comportamento varia com a natureza da lesão. A lesão isquêmica comparada à lesão tóxica (como aquela provocada pela injeção de veneno de cobra), injetada no músculo tibial anterior do camundongo, mostrou que a lesão isquêmica seria caracterizada por um infiltrado inflamatório mais extenso e a fase de fagocitose das miofibras degeneradas seria mais curto. Este fato levaria à produção precoce de células precursoras (satélites) por fatores liberados pelas células inflamatórias. A lesão tóxica mostrou maior conservação de membrana de miofibras necrosadas que serviam de suporte para fusão de células satélites (mpc) em miotubos e melhor microvascularização.

BODINE-FOWLER (1994), admitiu que o músculo esquelético tem uma grande capacidade de regeneração após lesão, seja parcial ou completa, de suas fibras. Entre os tipos de lesão inclui como lesões diretas: esmagamento, punção, incisões, congelamento, isquemia, aplicação local de anestésicos, exercícios excêntricos e uma grande variedade de doenças neuromusculares. 
Os fatores que limitariam a capacidade de regeneração do músculo esquelético após trauma ou doença seriam a população de células satélites viáveis, a reinervação e a revascularização.

CARLSON \& FAULKNER (1983) consideram a regeneração como a única adaptação do músculo esquelético que ocorre em resposta a uma lesão, a regeneração resultaria na restauração maior ou menor da estrutura original e função do músculo. Admitem que a regeneração de músculos esqueléticos é comparável, estrutural e funcionalmente, com a constituição do músculo durante o desenvolvimento embrionário.

BISCHOFF (1975), muniu-se de um sistema de cultura de células musculares esqueléticas isoladas de ratos adultos, com a finalidade de estudar a origem e o comportamento dos mioblastos mononucleares durante a regeneração muscular. Durante as primeiras poucas horas as fibras "in vitro" sofrem alterações degenerativas incluindo grumos miofibrilares de contração e picnose de mionúcleos.

ALBROOK (1962), afirma que a capacidade de fibras musculares estriadas sofrerem uma regeneração limitada após lesão é um fato bem estabelecido, mas a maneira precisa como isto ocorre está ainda aberto a investigações. O quadro citológico da necrose da fibra muscular e sua regeneração subsequente são complexos devido à variada velocidade das alterações morfológicas nas diferentes regiões da lesão e do numeroso tipo de células que tomam parte no processo regenerativo.

FISCHER et al. (1990), consideram que 6 a 24 h após o trauma do músculo, o segmento danificado mostra uma grosseira dilaceração e degeneração. Após 24 até 48 h há um aumento do número de núcleos sarcolemais, alguns dos quais são semelhantes às células satélites que se originam. Dentro de 3 dias células regeneradoras do músculo desenvolvem núcleos centrais e reorganizam sarcômeros.

NIKOLAOU et al. (1987), admitem que após lesão controlada, provocada por esforço, a cicatrização da lesão muscular 7 dias após apresentava inflamação reduzida e a fibrose por colágeno mais avançada. Os achados desses 
autores demonstraram que a recuperação funcional do músculo ocorre 48 horas após, a despeito da inflamação e da cicatrização ativas.

CRISCO et al. (1994), desenvolveram uma técnica reproduzível de lesar o músculo e passível de quantificação. Confirmam histologicamente diferentes estadios de lesão da fibra - lesão aguda, degeneração, regeneração e normalização. A função contrátil como indicativa de performance muscular, estaria significativamente comprometida pela lesão por contusão e melhorava a cada estágio histológico.

NOONAN et al. (1994), procuraram determinar as primeiras evidências da lesão muscular induzida por estiramento passivo em músculo de coelho. Consideram que alterações nas propriedades contráteis e o estágio histológico parecem ser mais sensíveis no prognóstico da lesão, que as medidas da falência das propriedades estruturais. Este estudo oferece clinicamente a evidência de que o uso do músculo que é portador de uma pequena lesão disrruptiva predispõe o indivíduo a uma lesão adicional .

BRASSEUR et al. (1997), no estudo da degeneração e regeneração de fibras musculares estriadas na distrofia de Duchenne, consideram que esta doença é caracterizada pela coexistência de lesões degenerativas de fibras musculares e de alterações regenerativas. Neste trabalho os autores procuram verificar o grau de regeneração em diferentes estadios da doença, analisando a expressão de vários marcadores de proliferação celular e diferenciação muscular. Estudando a expressão de marcadores musculares (vimentin, desmin, "isoforms of the myosin heavy chain") foi possível determinar-se o grau preciso de maturação e diferenciação de fibras em regeneração. Os resultados sugerem que uma regeneração abortada de fibras musculares na síndrome pode explicar, pelo menos parcialmente, a evolução progressiva da doença.

KUREK et al. (1996), admitem que um grande número de fatores de crescimento estão envolvidos na coordenação da proliferação e diferenciação de células musculares e, particularmente após lesão em doenças. O fator inibidor da leucemia (LIF) estimula fortemente a proliferação de mioblastos in vitro e in vivo, e sua expressão na lesão muscular sugere que o LIF pode ter um papel como um fator 
de trauma. Administrado a músculos de camundongos demonstrou estimular a formação de longos miotubos. Esta ação miotrófica indica que o LIF contribui para a regeneração do músculo.

HURME \& KALIMO (1992), consideram importante para a cicatrização da lesão muscular a remoção do material muscular necrosado por macrófagos da área da lesão o mais cedo possível, pois esse processo parece ser um pré-requisito para a ativação e proliferação de células satélites nas vizinhanças da área da lesão. A proliferação de células satélites deveria começar antes da granulação e que o tecido cicatricial prolifere excessivamente e obstrua a regeneração de células musculares através do intervalo entre os cotos das miofibras rompidas.

BISCHOFF \& HEINTZ (1994), afirmam que o músculo esquelético tem uma acentuada capacidade de regeneração sob condições experimentais; substanciais quantidades de músculo perdidas por lesão ou isquemia não são geralmente repostas em situações clínicas (KAKULAS,1982 apud BISCHOFF \& HEINTZ, 1994).

RANTANEN et al. (1999), trataram experimentalmente a lesão do músculo gastrocnêmio do rato com USP em lesão produzida por contusão. A velocidade da mioregeneração dos animais tratados com USP foi comparada aos controles por imunohistoquímica, morfometria e análise cintilográfica. Embora as células satélites tivessem aumentado $96 \%$ nos tratados com Ultra-Som durante os primeiros estágios da regeneração, não houve o mesmo efeito na produção de miotubos. O período de proliferação rápida de fibroblastos de 3 a 4 dias aumentou de 7 a 10 dias comparando-se o grupo controle com o tratado pelo USP, enquanto a recapilarização não foi afetada. Embora o USP promova um aumento na proliferação de células satélites na fase de mioregeneração, não parece ter efeitos significativos sobre as demais manifestações morfológicas da regeneração muscular.

SCHULTZ \& JERYSZAK (1985), em seus estudos observaram que as células satélites do músculo são as células tronco miogênicas que funcionam para reparar as fibras musculares lesadas. A participação das células satélites na resposta regenerativa à lesão muscular resulta numa significante redução de seu potencial 
cumulativo de proliferação. A magnitude da redução é proporcional ao número de respostas de regeneração nas quais elas participam.

DANILOV et al. (1996), estudaram as particularidades da regeneração após danos por tiro em coelhos. A fase inicial do processo seria a de uma zona de necrose pós-traumática, desintegração do tecido muscular esquelético e ativação de macrófagos. A fase proliferativa inicia-se 36 horas após a lesão e inclui a ativação de "miosatelitócitos", proliferação e aparecimento de mioblastos. O processo de diferenciação celular miogênica é semelhante àquela embrionária.

CHOU \& NONAKA (1977), afirmam que a formação de miotubos, característica habitual da miogênese, raramente ocorre no processo regenerativo instituído pelas células satélites em doenças dos músculos esqueléticos humanos.

BODINE-FOWLER (1994), no estudo da lesão muscular revelam que o músculo esquelético tem uma remarcável capacidade de regeneração resultante de lesão parcial ou total da fibra muscular. A regeneração segue numa seqüência característica e está limitada a três fatores: população de células satélites, reinervação e revascularização.

BISCHOFF (1990), estudou as miofibras com suas células satélites isoladas de ratos adultos para verificar a influência de miofibras maduras na proliferação de células satélites. As células satélites permanecem quiescentes quando cultivadas em meio contendo soro, mas proliferam quando expostas ao fator mitogenético extraído de músculos adultos esmagados. Os resultados indicam que o contato com a superfície de uma miofibra madura suprime a proliferação de células miogênicas mas as células não se fundem com a miofibra.

HURME \& KALIMO (1992), afirmam que núcleos de células satélites marcadas não aparecem antes que se iniciem a fagocitose de restos necrotizados. Geralmente um dia após o trauma muitos núcleos são encontrados na área de necrose de miofibras rompidas, enquanto que poucos deles na porção sobrevivente. É extensa a proliferação de células satélites no $4^{\circ}$ dia de regeneração e poucas marcadas no $7^{\circ}$ dia. Especula-se se o fator de crescimento liberado pelos macrófagos seria necessário 
em vista do decréscimo de células satélites marcadas ao $7^{\circ}$ dia. A maioria dos mionúcleos, necessária à regeneração de miofibras, é produzida precocemente dentro dos cilindros de lâminas basais preservadas e distribuídas naquelas partes das miofibras que se estendem entre o tecido conjuntivo e o muscular.

Como já havíamos visto, LEFAUCHER \& SÉBILLE (1995), estudaram os eventos celulares da degeneração e regeneração do músculo com vários modelos de lesão. A comparação da lesão isquêmica com a tóxica mostrou nesta, uma extensão do infiltrado inflamatório e um encurtamento da fase de fagocitose do dano das miofibras. Isto levou à diferenciação e proliferação de células precursoras (mpc) ocorrer mais precocemente o que pode ter sido promovido por fatores de crescimento liberado pelas células inflamatórias.

O início da regeneração muscular está estreitamente ou fortemente relacionado aos eventos que ocorrem durante a fase de regeneração. 


\section{MATERIAL E MÉTODOS}

\subsection{Animais de experimentação}

$\mathrm{Na}$ presente pesquisa foram utilizados 10 ratos albinos da variedade Wistar com pesos variando de 120-140 g e obtidos no biotério da Faculdade de Medicina de Ribeirão Preto. Colocados em gaiolas apropriadas, foram mantidos 24 horas no ambiente do laboratório para aclimatação. Durante o experimento e nos períodos pós-operatórios até o sacrifício, foram mantidos sob condições ambientais, com um ritmo circadiano de luz e escuro, recebendo água e ração balanceada $\left(\right.$ Purina $\left.^{\circledR}\right)$ à vontade.

\subsection{Técnicas Operatórias}

As lesões musculares, padronizadas, foram obtidas conforme os seguintes passos:

a) anestesia mediante injeção intraperitoneal de $\operatorname{Rompum}^{\circledR}$ e $\operatorname{Ketalar}^{\circledR}$ em quantidades iguais, na dose de $0.10 \mathrm{ml}$ da solução, para cada $100 \mathrm{~g}$ de peso do 
animal;

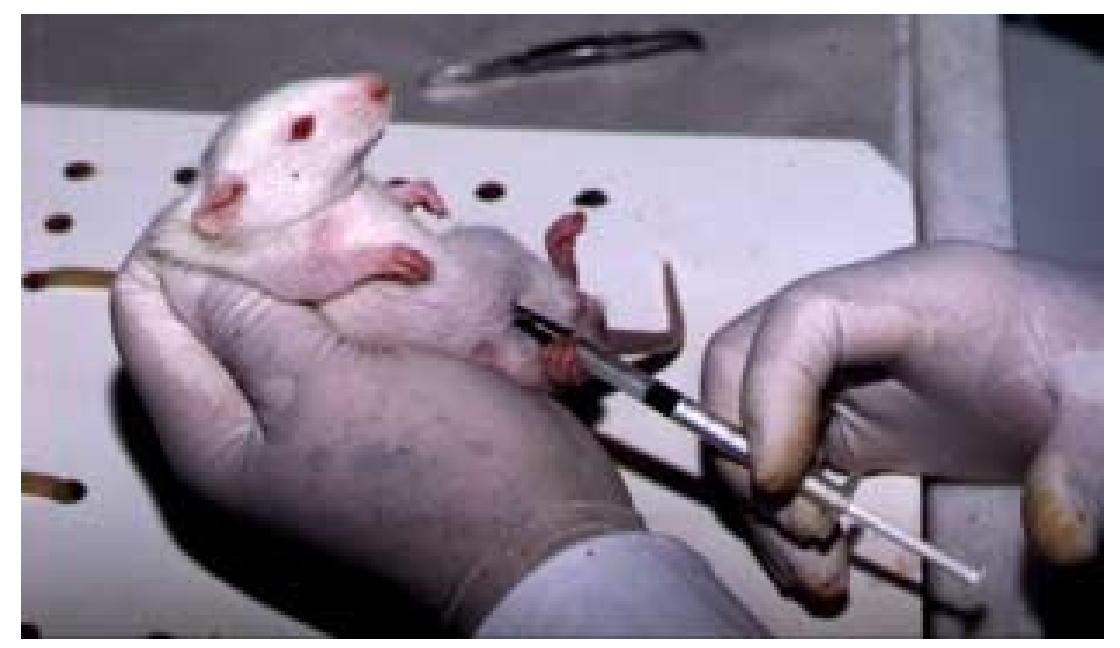

FIGURA12 - Anestesia mediante injeção intraperitoneal.

b) fixação do animal em prancha operatória seguida de tricotomia da face externa das coxas D e E;

c) após assepsia com álcool-iodado a $2 \%$ fazia-se uma incisão longitudinal com bisturi (lâmina 4), dos planos cutâneos e fáscia do músculo glúteo maior;

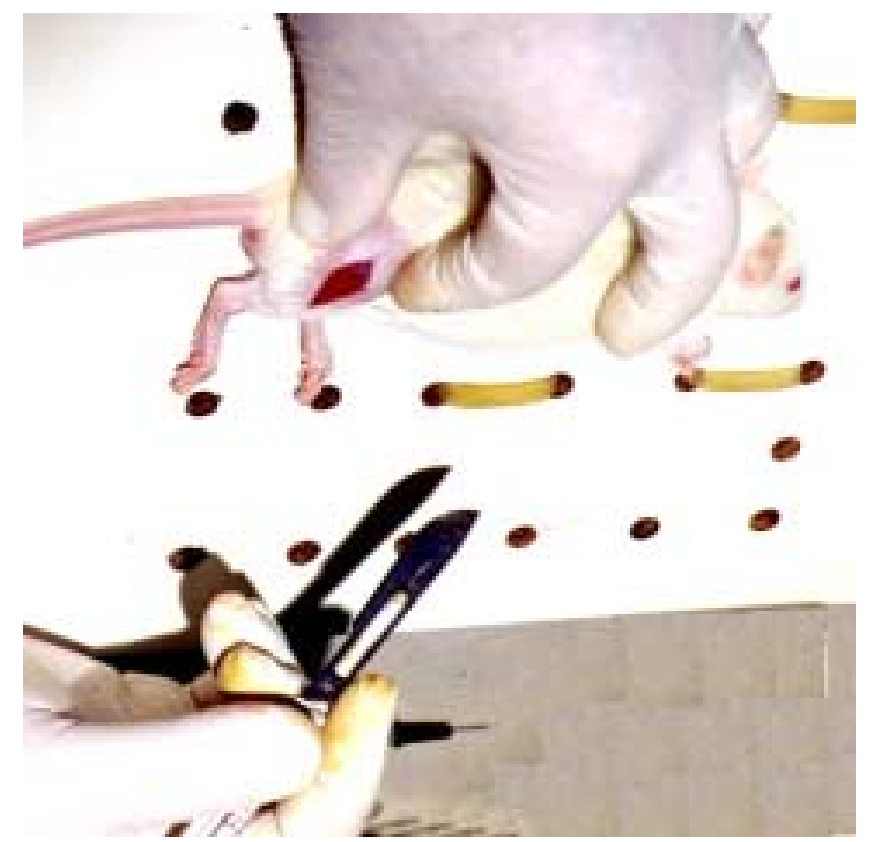

FIGURA 13 - Incisão dos planos superficiais. 
d) exposto o músculo faziam-se cortes perpendiculares às suas fibras alcançando, em profundidade, cerca de $2 / 3$ da espessura do músculo;

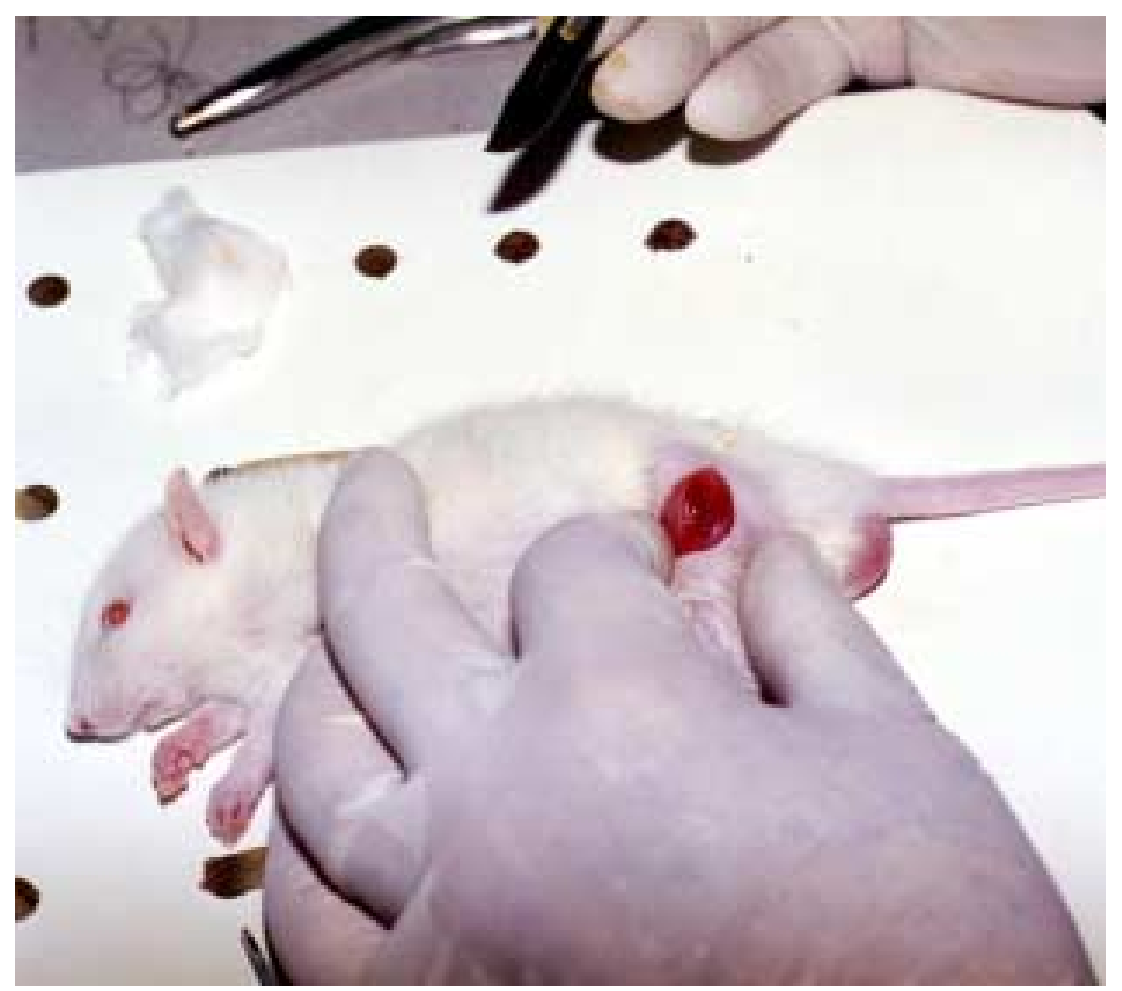

FIGURA 14 - Demonstrativos das incisões praticadas no músculo glúteo maior.

e) a seguir, as lesões musculares eram suturadas com fios de nylon 4.0, e pontos separados. A sutura dos planos superficiais também era feita com o mesmo tipo de fio e pontos separados;
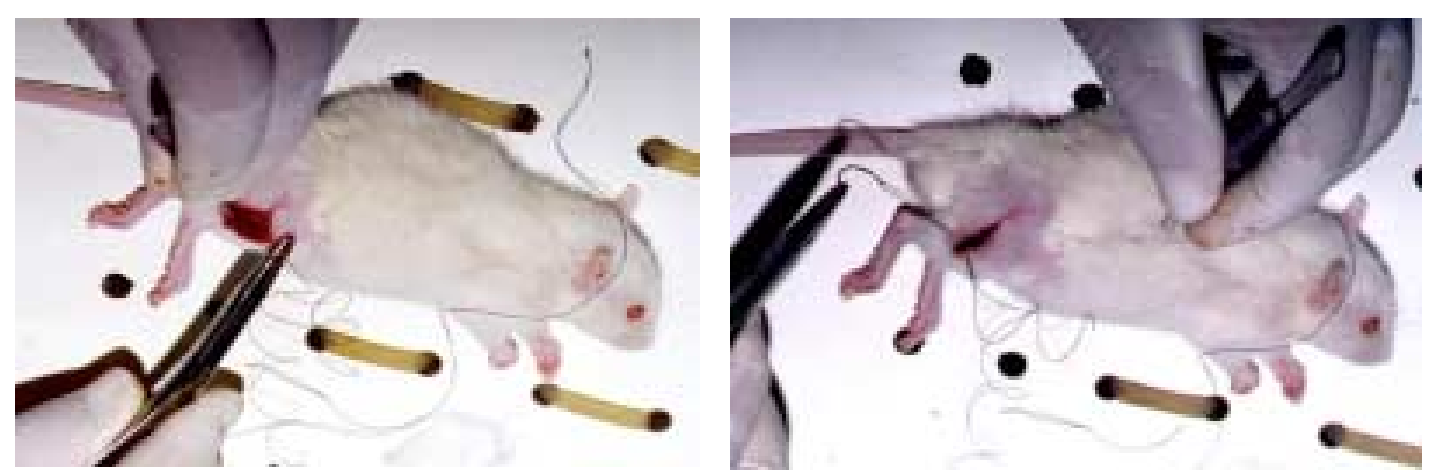

FIGURA 15 - Demonstrativo da síntese dos planos muscular e superficiais. 


\subsection{Estímulo ultra-sônico}

Após as incisões nos músculos das duas coxas, marcaram-se os animais para compor os 3 grupos experimentais, de maneira aleatória. Compostos os grupos, procedeu-se um sorteio para o sacrifício após 3, 6 ou 10 dias de aplicação do USP. O equipamento utilizado tinha as seguintes características: freqüência fundamental de 1,5 MHz, pulsado, frequiência de repetição dos pulsos de $1 \mathrm{kHz}$, largura de pulso de $200 \mu$ s. Os tecidos, alvos deste trabalho, foram submetidos ao campo próximo do transdutor, onde a intensidade medida foi de $16 \mathrm{~mW} / \mathrm{cm}^{2}$ em meio aquoso.

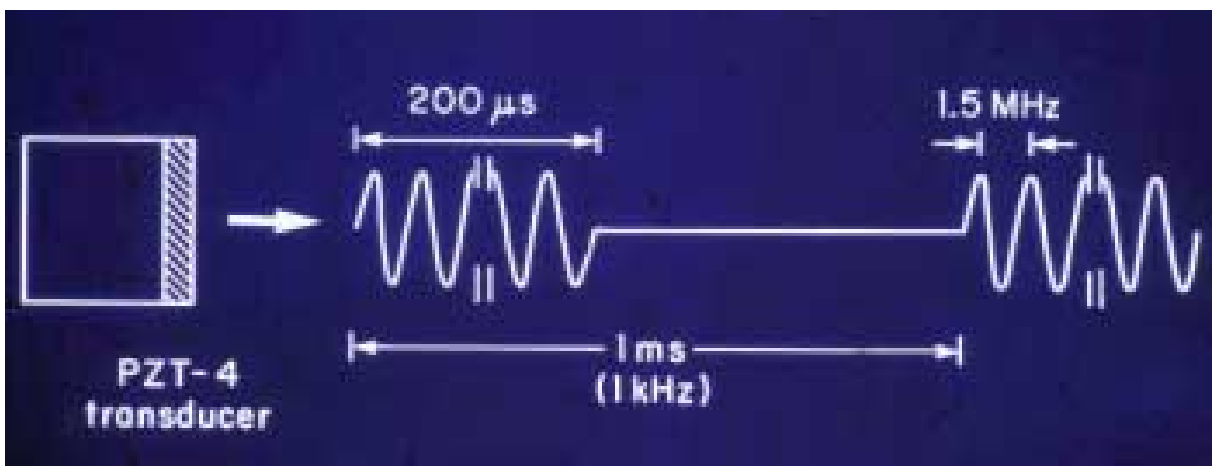

FIGURA 16 - Sinal elétrico que excita o transdutor ultra-sônico pulsado.

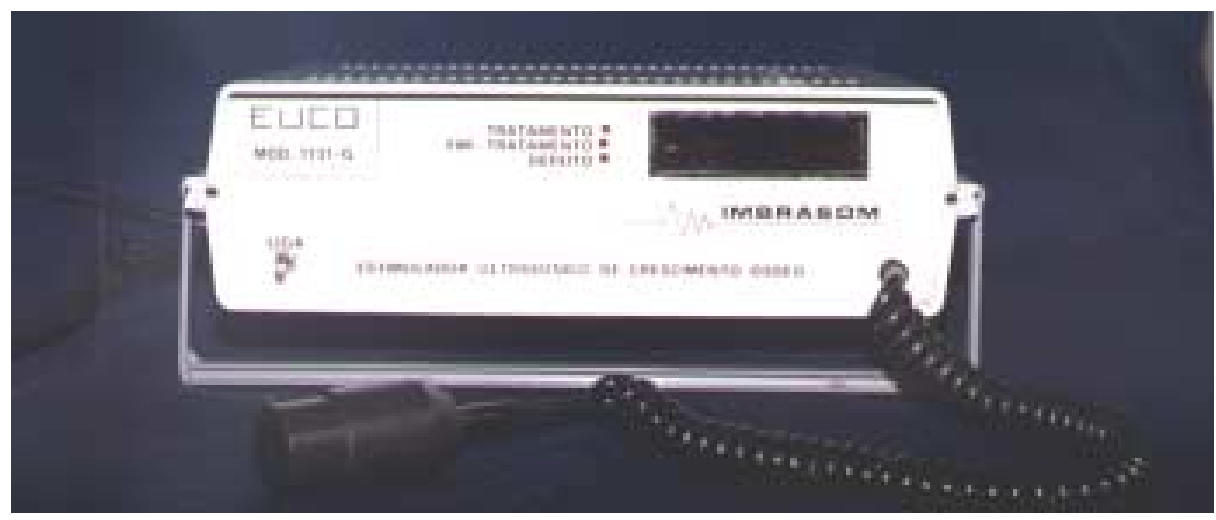

FIGURA 17 - O aparelho de USP (produzido no Laboratório de Bioengenharia do Grupo de Bioengenharia do Departamento de Engenharia de Materiais, Aeronáutica e Automobilística da EESC - USP). 
Todos os animais só foram estimulados após decorridos 24 horas da cirurgia. Os animais foram estimulados sempre do lado direito com o USP, sendo o transdutor aplicado de maneira estacionária acoplado com hidrogel. Cada aplicação durava dez minutos a cada dia, pela manhã e o lado esquerdo, que servia como controle era submetido a uma sonicação fictícia (Figura 18).

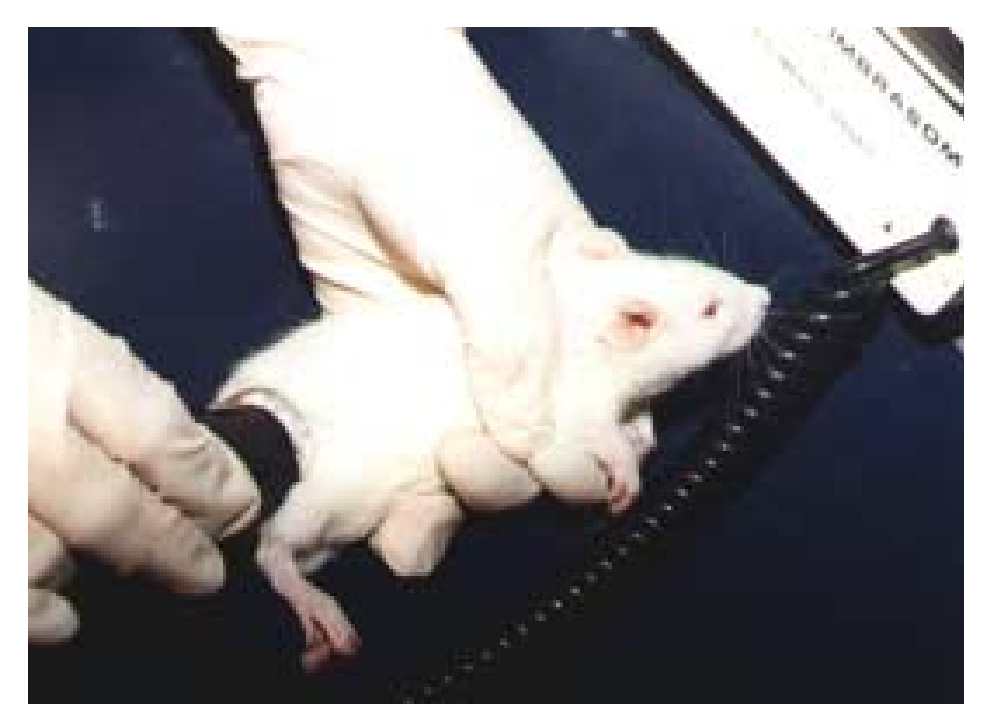

FIGURA 18 - Figura representativa de estimulação estática com o transdutor ultrasônico.

\subsection{Elaboração do tecido muscular para o estudo histológico}

Para o estudo histopatológico, e para avaliar a multiplicação celular, os animais foram inoculados, via intraperitoneal, com $0,15 \mathrm{ml}$ de uma solução padrão de Colchicina para cada 100 gr de peso, 6 horas antes do sacrifício. (Colchicina cedida pela Prof ${ }^{a}$. Dr ${ }^{\mathrm{a}}$. Catarina Satie Takahashi do Depto de Genética da USP Faculdade de Filosofia).

Os animais, decorridos os tempos estabelecidos para a aplicação do USP, foram sacrificados por inalação excessiva de éter etílico. Os músculos eram 
reduzidos a fragmentos contendo uma porção da área lesada pelas incisões e os pontos de sutura do tegumento eram retirados, assim como os pontos que foram dados nos músculos.

Após fixação em solução fixadora de Bouin por cerca de 2 horas, os fragmentos musculares eram processados rotineiramente para inclusão em parafina e posterior obtenção de cortes histológicos com $6 \mu \mathrm{m}$ de espessura.

Os cortes foram corados com hemalumem e eosina. As lâminas contendo os cortes corados, foram examinadas e fotografadas em fotomicroscópios Zeiss sob diferentes aumentos. 


\section{RESULTADOS}

$\mathrm{Na}$ exposição dos resultados procurou-se seguir uma ordenação de acordo com a proposta inicial do trabalho.

Convencionou-se conduzir o experimento de modo que o músculo do lado direito, submetido às incisões, seria o estimulado por 3, 6 e 10 dias, enquanto que o do lado esquerdo, igualmente submetido às incisões, seria submetido a uma estimulação fictícia, por períodos equivalentes.

A regeneração do músculo estriado ou esquelético adulto, independentemente do tipo de lesão, obedece a um cortejo de fatos, ou etapas, mais ou menos bem definidas e caracterizáveis histopatologicamente.

Aproveita-se a oportunidade de dizer aqui, porém, para posterior discussão, que nem todos os fatos relacionados à regeneração do músculo esquelético estão, até hoje, bem esclarecidos.

Da seqüência de eventos caracterizáveis histopatologicamente durante a regeneração muscular, tem-se de início uma necrose tecidual com a mobilização de células inflamatórias, seguida de fagocitose de restos celulares pela ação de macrófagos provindos da circulação sangüínea adjacente à área de necrose.

À necrose seguem-se a revascularização e a proliferação de células mioprecursoras, ou satélites (MAURO, 1961), também chamadas de miogênicas. Em seguida estas células se diferenciam em mioblastos os quais se fundem para 
constituir os miotubos, que por sua vez amadurecem e se transformam em novas fibras musculares (LAWSON-SMITH \& McGEACHIE, 1998).

A regeneração muscular em quaisquer dos modelos experimentais, seja por incisões ou traumatizando fibras musculares, nas quais apenas parte das fibras são lesadas, são seguidas de um modelo rápido e completo de regeneração (CHURCH, 1970; CHURCH, apud MAURO et al., 1970; SCHULTZ et al., 1985).

A velocidade de regeneração, entretanto, não ocorre naqueles modelos aos quais a perda muscular (injeção de tóxicos, p.e.) é muito intensa (BENOIT \& BELT, 1970; ONO et al., 1993).

Na Figura 19, estão documentados, mediante fotomicrografias, aspectos histopatológicos da evolução da necrose das áreas incisionadas de músculos de animais não estimulados, aos 3 e 6 dias após lesão. Pode-se verificar uma intensa inflamação, com restos celulares de fibras lesadas. Com a administração da colchicina, células inflamatórias e células precursoras da miogênese estão com seus núcleos bloqueados em metáfase. Notar que aos 6 dias diminui o número de células inflamatórias e já há a formação de fibroblastos jovens de permeio a restos celulares e células satélites.

Após estímulo pelo USP, aos 3 dias, observa-se restos de células musculares, diminuição das células inflamatórias e uma intensa neoformação vascular. Em alguns casos já há a confluência de mioblastos agregando-se para formar miotubos, cujos extremos estão voltados para a área de reparo da necrose (19D).

A necrose é a primeira ocorrência que se segue ao dano causado às fibras musculares. É o primeiro acontecimento reconhecível histopatologicamente, e que em geral fica restrito ao centro da área lesada. Procurou-se na Figura 19 documentar o centro das áreas de necrose. 

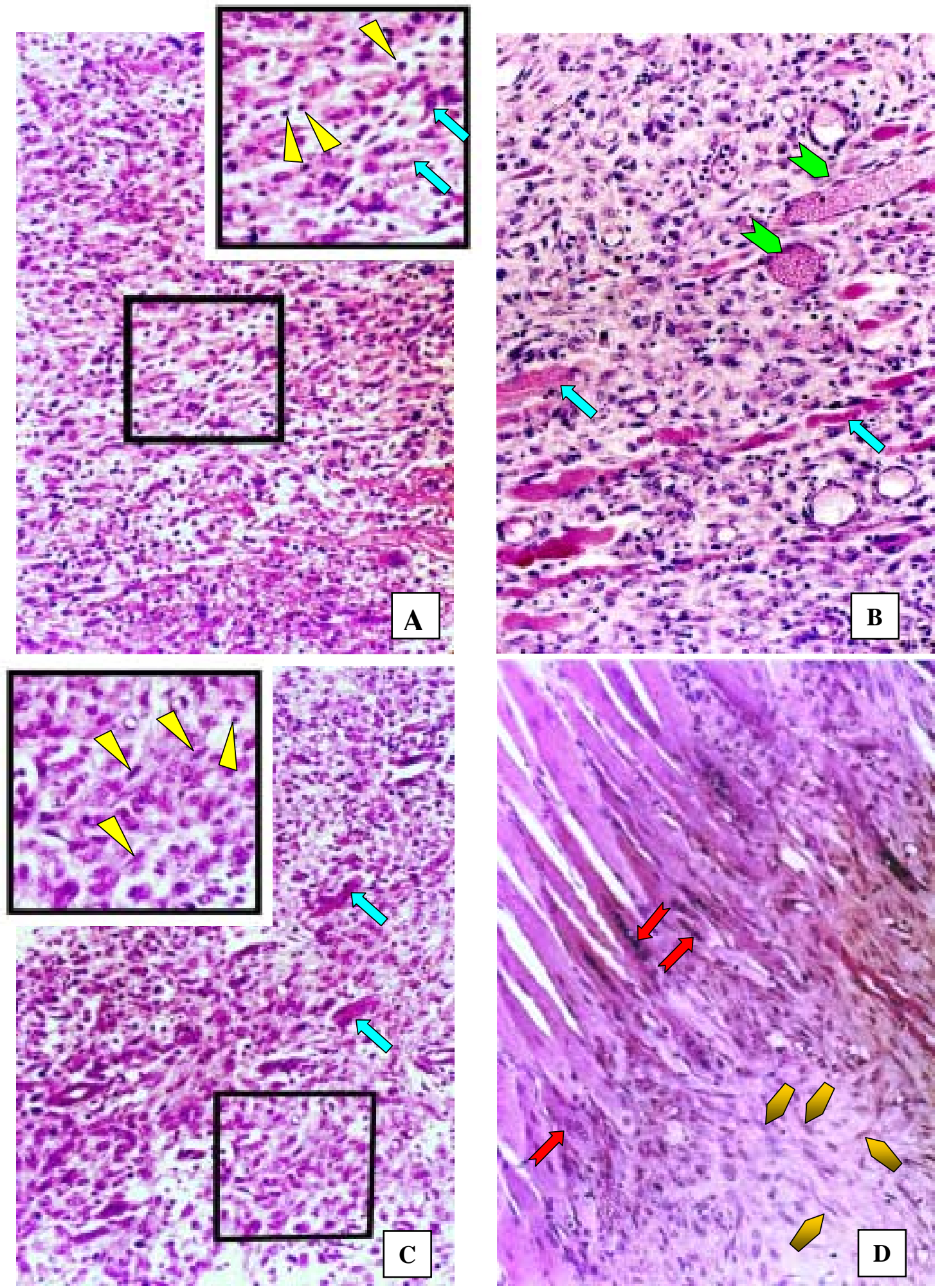

FIGURA 19 - As fotomicrografias A e C correspondem a áreas de necrose de músculos de animais controles (sem estímulo) após 3 e 6 dias, respectivamente. As fotomicrografias B e D representam as mesmas áreas de necrose em músculos de animais estimulados por 3 dias com o ultra-som pulsado. Notar, acima, a intensa proliferação de vasos neoformados $(\hat{Q})$, em meio a restos de fibras musculares ( $\Longrightarrow$ e uma diminuição do infiltrado inflamatório $\square$ ). Alguns animais estimulados (B e D), já apresentam fibroblastos( $\square$ ) e início de formação de miotubos $\Leftrightarrow$ ). Cortes de $6 \mu \mathrm{m}$, corados pelo H.E. Aumento A, C e D de 192x; B de 384x; nos destaques aumento de $288 \mathrm{x}$. 
Após a lesão, a necrose das fibras lesadas que ocorre precocemente é caracterizada pela grande mobilização de células inflamatórias, enquanto que as fibras musculares situadas distantes da lesão permanecem íntegras, mesmo porque o músculo não fora denervado. A irrigação das fibras não envolvidas na área de necrose é preservada.

Em seqüência à fase inflamatória, inicia-se a fagocitose de restos celulares, por macrófagos migrados da circulação adjacente para a área de necrose. Estudos têm demonstrado que este fato ocorre 24 a 48 horas após. A tendência é a evolução da necrose para uma fibrose reparadora.

As metáfases observadas na sua maioria são de células que futuramente vão se transformar em mioblastos (possivelmente metáfases de núcleos de células miogênicas - m.p.c.).

Não se pode assegurar, entretanto, que todos os núcleos em metáfase sejam de células satélites ou precursoras, mas provavelmente de fibroblastos ou de outras células inflamatórias mobilizadas para resolver o processo de necrose, pois são indiferentemente bloqueados pela colchicina.

Compõe-se a Figura 20 de fotomicrografias de músculos de animais controle, sem estímulo, e de animais estimulados pelo USP. 

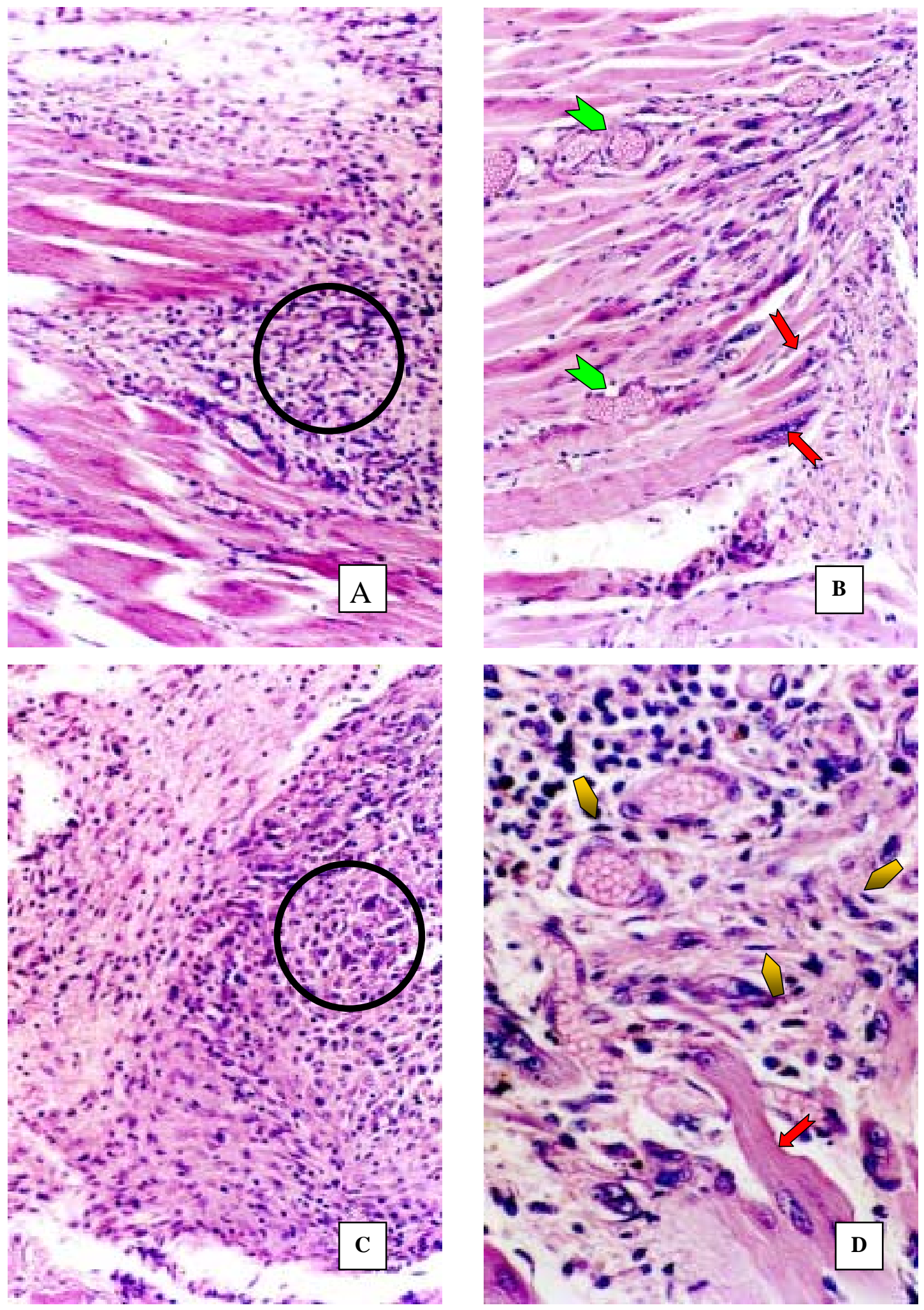

FIGURA 20 - As fotomicrografias da figura ilustram o músculo de 2 animais controles (A e C) e de 2 animais estimulados pelo ultra-som pulsado (B e D) durante 10 dias. Nos animais controles há ainda necrose em evolução (circulo), nos animais estimulados há intensa neovascularização ( $\square$ ), início de migração de células satélites para restos de membranas, visando a formação de miotubos $(\Longrightarrow)$ e a formação de fibroblastos $(\square)$. Cortes de $6 \mu \mathrm{m}$ corados pelo H.E.. Aumento: A, B e C de 192x e D de 480x. 
Enquanto nos músculos estimulados, há formação de vasos, alguns de parede já constituída e contendo sangue (animais estimulados por 10 dias), naqueles não estimulados há ainda zonas de necrose, infiltrados inflamatórios e restos celulares.

A agregação de mioblastos nos animais estimulados é também evidenciada.

Pode-se constatar que mesmo decorridos 10 dias após lesão, nos animais não estimulados havia ainda necrose, enquanto que nos estimulados, além de intensa neoformação vascular (que é induzida precocemente), ocorreu também a agregação de mioblastos em colunas.

Na Figura 19B (página 69) pode-se também notar a flagrante quantidade de núcleos em metáfase na fotomicrografia de um animal estimulado por 3 dias, o que permite supor que o USP estimula também a produção celular, especialmente de células miogênicas. Entretanto não se pode configurar na maioria dos núcleos bloqueados um volume de citoplasma que pudesse caracteriza-los como núcleos de mioblastos, ou que nem todas as mitoses bloqueadas correspondam a núcleos de células mioprecursoras.

O evento decisivo na regeneração do músculo esquelético é a proliferação de células miogênicas precursoras e sua diferenciação em mioblastos.

Nem todos os músculos esqueléticos dentro de uma mesma espécie animal têm a distribuição linear de células satélites semelhante (CAMPION, 1984). Além disso, a relação entre células satélites e núcleo de fibras é de 1:9.

As células satélites existem em associação com vários tipos de fibras descritas no músculo esquelético (SCHMALBRUCH \& HELLHAMMER apud CAMPION, 1984). As células satélites não aparecem antes que os restos de tecidos necrotizados tenham sido fagocitados, geralmente um dia após o trauma (fácil de ser constatado nas figuras nas quais estão representados músculos que foram estimulados). A maior parte das células satélites está localizada na porção necrosada 
das miofibras rompidas, enquanto apenas poucas se localizam na região de fibras não lesadas e em geral situadas a uma certa distância da área de lesão ou necrose (Figura 22).

Alguns autores (HURME \& KALIMO, 1992) não admitem a migração de células satélites, considerando que a maioria das células satélites é produzida localmente ou próximo ao local da lesão.

Na Figura 21 estão fotomicrografias que documentam metáfases de núcleos, que se constituem em mioblastos característicos de animais estimulados pelo USP por 3 dias. Estas células parecem ter a capacidade de migrar de células vizinhas íntegras ou de células musculares que estiveram envolvidas na degeneração necrótica.

Comparando-se as três fotomicrografias podemos verificar que no animal não estimulado (A), há maior número de células inflamatórias, enquanto que nos animais estimulados (B, C) parece haver uma "indução" para a formação de mioblastos e para que estes se agreguem.

Alguns mioblastos parecem estar penetrando em restos de membrana celular de células degeneradas, para constituir futuros miotubos (Figura 21C).

Miofibras isoladas com células satélites isoladas de ratos adultos foram usadas para verificar a influência da fibra madura em relação à proliferação celular. Embora experiências desta natureza sejam conduzidas "in vitro" e portanto difíceis de serem extrapoladas para o comportamento da regeneração muscular "in vivo", alguns fatos parecem conciliar o que aqui foi exposto. As células satélites seriam estimuladas em presença de extratos de músculos adicionados ao meio de cultura, enquanto isto não é feito, elas permanecem quiescentes. O contato da célula satélite com a miofibrila suprime a proliferação das mesmas, mas estas não se prendem a miofibra. Admite-se também que o número de células satélites esteja relacionado com o grau de regeneração das fibras. 

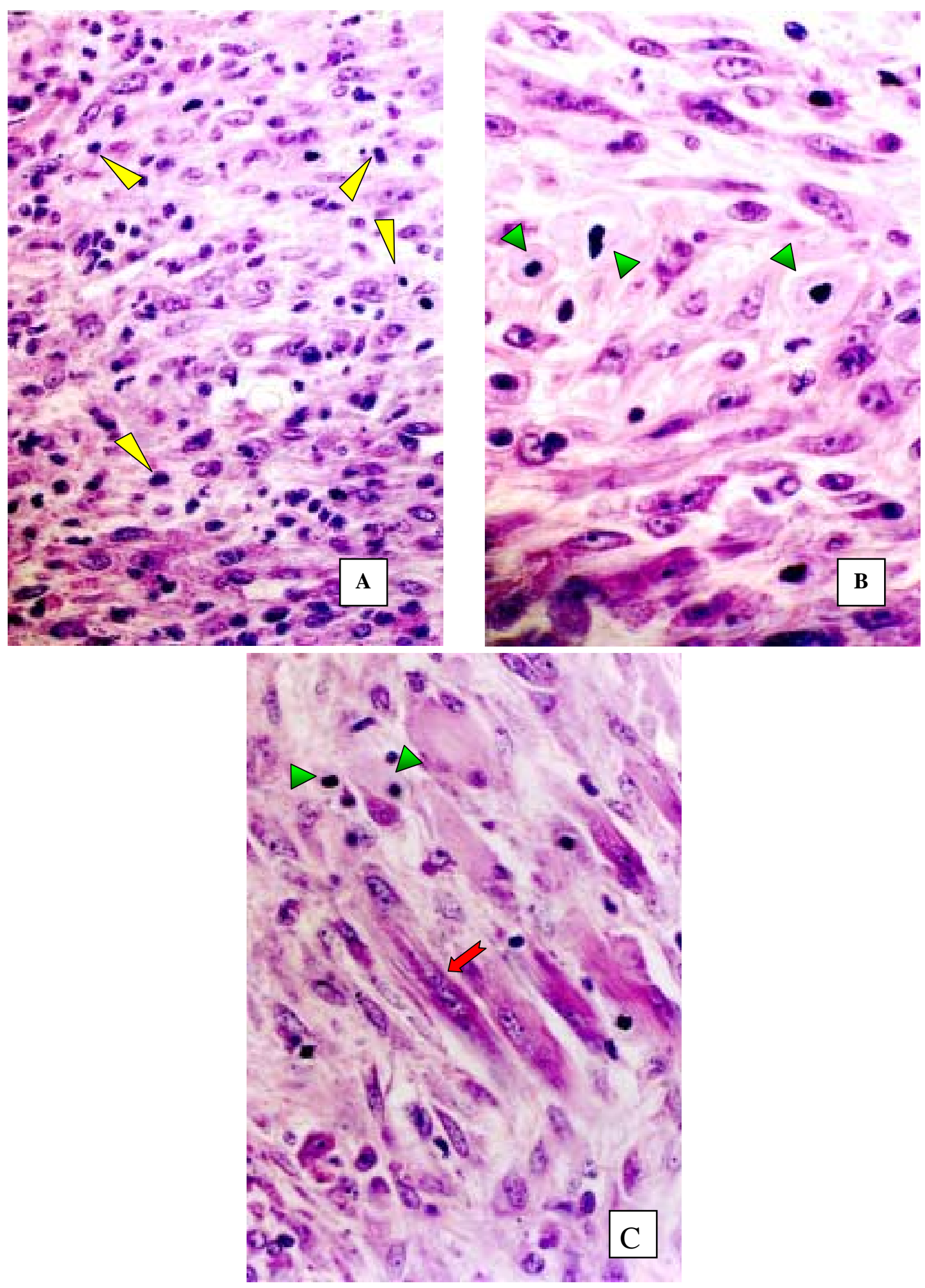

FIGURA 21 - As fotomicrografias são demonstrativas das diferentes células de tecido muscular com 3 dias cujos núcleos em divisão foram bloqueados pela colchicina. Na foto $\mathrm{A}$ indicativo de músculo de animal não estimulado cuja lesão acha-se em fase inflamatória( $\square$ ). $\mathrm{Na}$ foto $\mathrm{B}$, de um animal estimulado, estão indicadas metáfases de núcleos de células satélites em divisão (mioblastos) $(D)$. Na foto $\mathrm{C}$ mioblastos, também de animal estimulado, agregando-se para constituir miotubos $(\Longrightarrow)$. Cortes de $6 \mu \mathrm{m}$ corados pelo H.E. Aumento: A e $\mathrm{C}$ de $480 \mathrm{x}$ e B de 1200x. 
Ao se examinar a Figura 22, pode-se constatar que no animal estimulado, as fibras íntegras, longe da área lesada, apresentam estriação e células satélites em metáfases. Enquanto este fato é mais raro nas fibras dos animais não estimulados. A simples observação dos núcleos das fibras mostra igualmente diferença na morfologia e na basofilia dos mesmos.
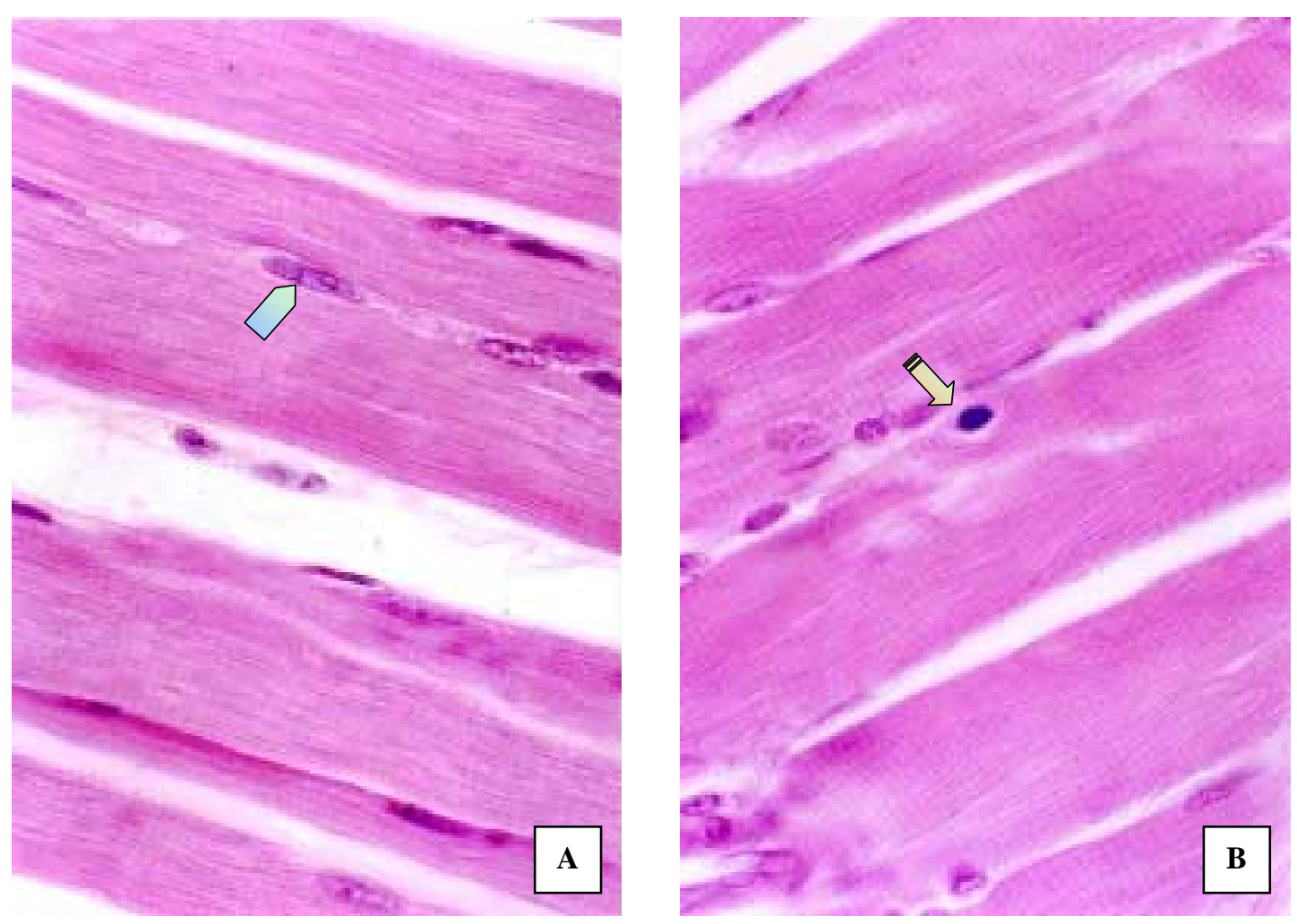

FIGURA 22 - Fotomicrografias de células musculares normais, distantes da área de lesão com 10 dias. A foto A mostra células musculares não estimuladas ( $\square$ ). A foto $B$, trata-se de músculo estimulado, mostrando um núcleo de célula satélite em metáfase $(\mathbb{I} \cdot \vec{r})$. Notar que o núcleo acha-se isolado da sarcolema da célula. Cortes de $6 \mu \mathrm{m}$ corados pelo H.E. Aumento de 480x.

Músculos de animais estimulados por 10 dias consecutivos mostram a presença ainda de numerosas células satélites bloqueadas em metáfase e em contato ou nas proximidades de miotubos próximos à área da lesão. O número porém, de metáfases reduz quantitativamente, embora não tenhamos feito nenhum tipo de contagem, mas apenas avaliando a quantidade de metáfases encontradas aos 3 dias e 10 dias após estímulo. Nas fotomicrografias da Figura 23 verifica-se a formação de numerosos miotubos e um decréscimo de núcleos de células miogênicas em 
metáfase. É notável também o número de núcleos por miotubo.
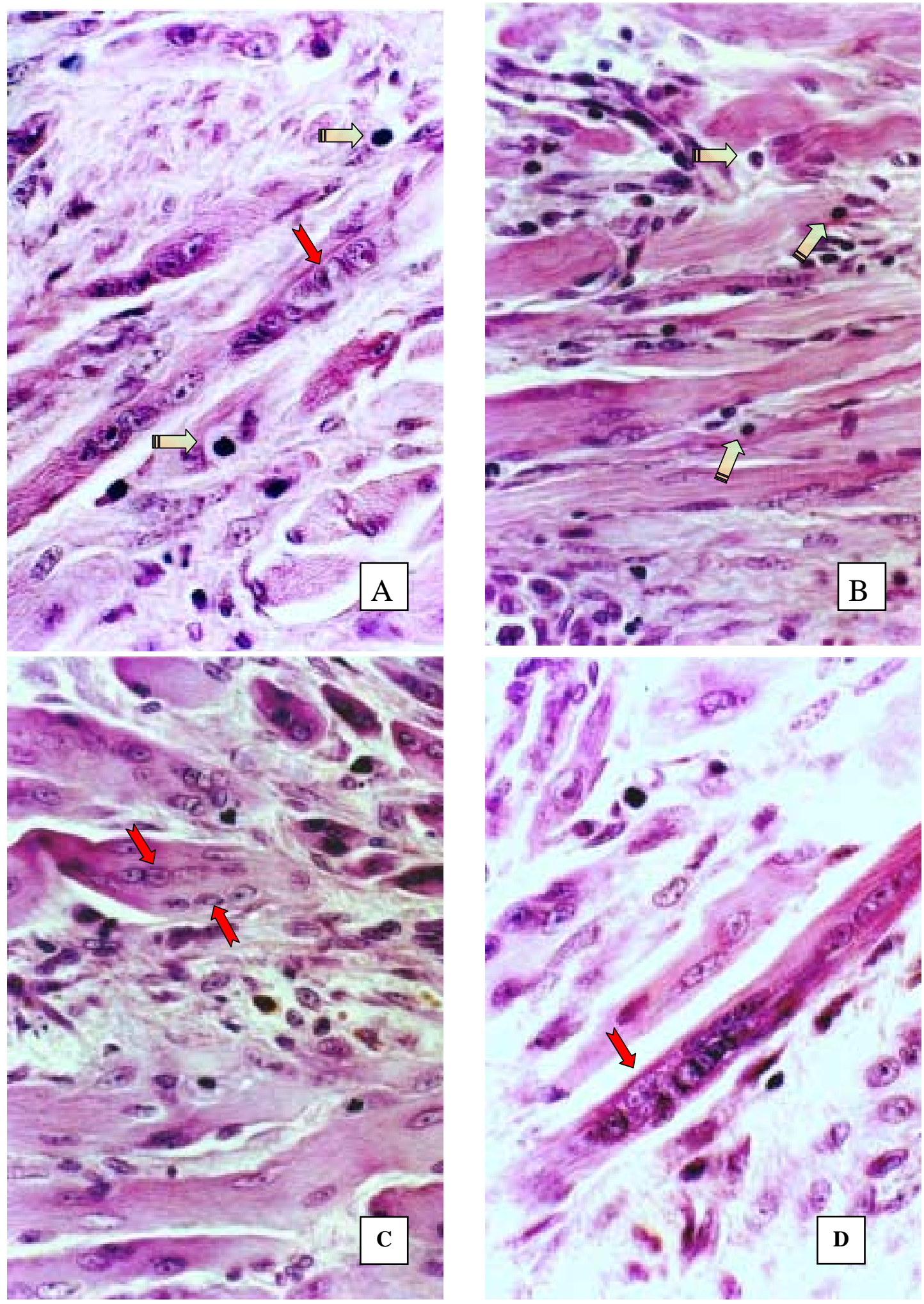

FIGURA 23 - Fotomicrografias de miotubos $(\Longrightarrow)$ de músculos de animais estimulados pelo ultra-som pulsado por 10 dias consecutivos. Apresentam várias metáfases de núcleos de células miogênicas $(\|)$, miotubos com numerosos núcleos enfileirados. Cortes de $6 \mu \mathrm{m}$ corados pelo H.E.. Aumento: A e D de 480x; B e C de 192x. 
O número de núcleos existentes nos miotubos (em alguns chegando a várias dezenas) parece decorrer da adição de mioblastos já que é consenso a regeneração muscular fazer-se de maneira semelhante, seguindo, estrutural e funcionalmente, o que ocorre durante o desenvolvimento embrionário do músculo. Para esclarecimento do leitor sugere-se reportar ao esquema da evolução embrionária de uma fibra muscular à página 43.

O processo regenerativo, quaisquer sejam os tipos de agentes lesivos e lesões provocadas, parece seguir um esquema relativamente rígido e comum a todos os tipos de lesões, exceto aquelas determinadas por agentes tóxicos ou com grande perda de substância muscular.

Segundo alguns autores o exercício facilitaria a regeneração, mas pouco se sabe quanto ao início ou quanto à intensidade adequada dos mesmos para o favorecimento da regeneração.

O sucesso da regeneração muscular após lesão requer a ativação das células satélites dormentes, as quais estão contidas na lâmina basal das células musculares adjacentes. Em presença de uma adequada vascularização, proliferam em miotubos, os quais certamente irão evoluir para novas células musculares, fatos demonstráveis nas fotomicrografias ilustrativas de etapas da nossa experimentação.

A Figura 24 representativa de miotubos de músculos estimulados por 10 dias, mostrando a formação de miofibrilas, caracterizando a maturidade da célula muscular regenerada. 


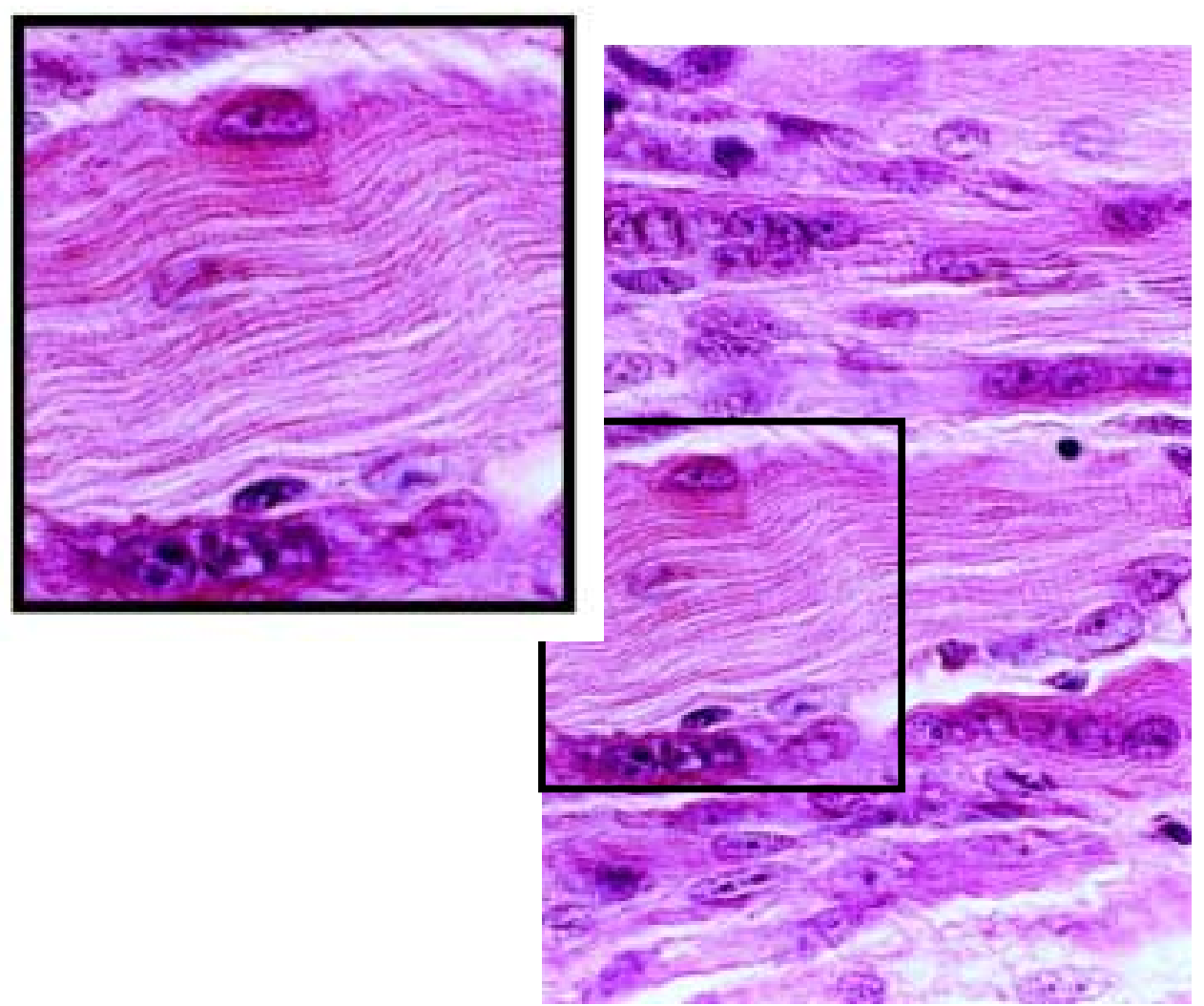

FIGURA 24 - Fotomicrografia de uma célula muscular estimulada por 10 dias e formando miofibrilas (no destaque) tendendo a se constituir numa célula muscular normal. Corte de $6 \mu \mathrm{m}$ corados pelo H.E.. Aumento de 480x e no destaque de 720x. 


\section{DISCUSSÃO}

Os trabalhos desenvolvidos para aumentar a compreensão sobre a regeneração muscular, com conseqüente uso pela fisioterapia, procuram estudar a dinâmica muscular após lesão, tão comuns em clínica fisioterapêutica. Assim, são utilizados alguns modelos de tratamento, muitos deles objeto de trabalho da fisioterapia (como o USP), que apesar de muito utilizados, ainda carecem de informações científicas a respeito de seus efeitos sobre a recuperação do músculo esquelético lesado. A intenção é que, posteriormente, possam ajudar a embasar protocolos de reabilitação mais eficientes para os indivíduos acometidos pelas lesões musculares.

Não foi encontrado na literatura relacionada com o assunto que ora pesquisou-se senão apenas dois trabalhos nos quais os autores utilizam-se do USP para avaliar os efeitos do mesmo sobre a regeneração de músculo estriado.

É pertinente lembrar que o aumento local da temperatura com os parâmetros usados no presente trabalho é considerado desprezível (DUARTE, 1987; HADAAD, 1992; ZISKIN, 1989), portanto os resultados decorrentes do uso do Ultra-som, neste experimento, devem-se exclusivamente aos mecanismos nãotérmicos.

A capacidade das fibras musculares esqueléticas se regenerarem é uma realidade estabelecida e aceita pelos citologistas, muito embora numerosos profissionais engajados no tratamento de pacientes com lesões musculares, 
permaneçam ainda desconhecendo esta realidade. Após uma lesão muscular grave, entretanto, uma certa quantidade de fibras, entra em necrose e não se recupera mais funcionalmente.

A membrana sarcolemal que envolve as fibras na área de necrose fica porém, geralmente e parcialmente preservada e espessada, podendo esvaziar-se de seu sarcoplasma. O espaço entre fibras lesadas sofre inicialmente um edema e/ou hematoma (KÄÄRIÄINEN et al., 1998), e após cerca de 12 horas é invadido por um infiltrado celular inflamatório que migra para a área lesada e passados 4 dias, o infiltrado celular diminui. São substituídos por fagócitos (macrófagos) que migram para a área lesada com a finalidade de remover e fagocitar restos celulares da área de necrose.

Dentro de 4 a 6 dias após a lesão das células, os tubos sarcolemais são liberados dos detritos da necrose inicial se alinham em colunas de mioblastos agregados.

WALKER (1963), por um processo de exclusão, admitia que os mioblastos se originariam de células musculares. Outros autores entretanto relacionam-os às células satélites (MAURO, 1961); MUIR et al. (1965) afirmam que esses mioblastos formariam um sincício alongado dentro dos tubos sarcolemais nos quais se dispõe como uma longa cadeia de núcleos. Nestas células, que os autores chamam agora de "miotubos" apareceriam precocemente miofilamentos abaixo da membrana plasmática, fato demonstrado a microscopia eletrônica por ALBROOK (1962). Outros autores (HOLTZER et al., 1957) evidenciaram a formação de miofilamentos com o emprego da antimiosina fluorescente, demonstrando que se dispunham de cada lado das cadeias de núcleos dos miotubos.

Os achados desta pesquisa, entretanto, mostraram que antes da constituição dos miotubos o processo regenerativo do músculo lesado apresenta a formação de um tecido semelhante ao tecido cicatricial, com grande quantidade de vasos neoformados induzidos pelo USP nos animais estimulados, pois nos animais controle a proliferação de vasos neoformados não ocorre no local da área de necrose muscular. 
É fato notável também que o USP induz a uma multiplicação celular intensa, quer de células satélites, que se transformarão em mioblastos, quer de células inflamatórias ou de outra natureza, provavelmente fibroblastos (vide Figura 20).

Estes achados que estão demonstrados nas fotomicrografias contradizem com aqueles de RANTANEN et al. (1999), que empregando o USP, mas usando parâmetros e tempos diferentes (USP de $2 \mu$ s de duração a intervalos de $10 \mu$ s (20\%) a uma frequiência de $3 \mathrm{MHz}$ e uma intensidade de $1,5 \mathrm{~W} / \mathrm{cm}^{2}$, transdutor estacionário durante 6 minutos), admitem que o único efeito do USP seria o de promover o aumento de células satélites (até 96\%), durante os estadios iniciais da regeneração, mas não obteve tal efeito na produção de miotubos. $\mathrm{O}$ mesmo autor considera que o período de produção de fibroblastos, que nos controles ocorreu rapidamente, entre o $3^{\circ}$ e $4^{\circ}$ dias, no grupo tratado, essa proliferação estendeu-se por 7 a 10 dias, enquanto a recapilarização era virtualmente inalterada.

Os achados desta pesquisa não condizem com os de RANTANEN et al. (1999), pois é flagrante a maior quantidade de vasos neoformados induzidos pelo USP bem como a constituição de miotubos em maior quantidade nos músculos estimulados e mais precocemente.

GOUVEA et al. (1998), usando o ultra-som terapêutico pulsado (freqüência de $1 \mathrm{MHz}$, intensidade de $0,5 \mathrm{~W} / \mathrm{cm}^{2}$, pulsado $1: 5$, durante 5 minutos) propuseram-se estudar a regeneração de fibras musculares do músculo tibial anterior de ratos, mediante lesões chamadas pelos autores de "incisivas". Admitem que o "padrão histológico" (sic) do músculo lesado e tratado com ultra-som foi muito diferente do "padrão histológico" do músculo controle. A reação inflamatória foi acelerada pelo ultra-som, o que possibilitou uma remoção mais eficiente das fibras necróticas do músculo. Apresentou maior número de vasos e fibras recém-formadas. O ultra-som estimulou a regeneração muscular com correspondente diminuição do tecido "fibrótico". Embora os achados desta pesquisa, sob alguns aspectos, assemelham-se aos dos autores citados, fica difícil uma comparação pois estes autores avaliaram os aspectos histopatológicos em cortes transversais do músculo. 
Um fato importante, até pouco tempo não reconhecido, é que as fibras musculares são constituídas a partir da coalescência de mioblastos. Este fato foi reconhecido em cultura de tecido muscular (KONIGSBERG, 1961). Esta ocorrência foi evidenciada mediante a marcação de núcleos com isótopos radioativos e células individuais com antimiosina fluorescente para detectar a natureza da população celular (HOLTZER, MARSHAL \& FINCK, 1957; WALKER 1963).

Examinando as Figuras 19D e 20B pode-se constatar que os miotubos decorrentes da agregação de mioblastos são mais precoces nos animais estimulados com o USP.

O emprego do USP condiz com as idéias de BISCHOFF \& HEINTZ (1994) os quais admitem uma grande capacidade de regeneração do músculo esquelético sob variadas condições experimentais e que diante deste fato, novas estratégias deveriam ser utilizadas com a finalidade de induzir um aumento da regeneração de fibras musculares.

Uma efetiva regeneração muscular requer células satélites e condições para a miogênese. As células satélites (descobertas há cerca de 30 anos por MAURO, 1961) constituem-se na única fonte de células miogênicas "tronco" no músculo esquelético adulto.

Segundo SCHMALBRUCH apud BISCHOFF \& HEINTZ (1994), a frequiência de células satélites no músculo maduro é da ordem de $5 \%$ de todos os núcleos que se situam dentro da lâmina basal, com variações, dependendo da espécie animal e tipo de músculo. As células satélites mantêm-se viáveis mesmo após tratamento que matam ou alteram as miofibrilas, tais como: esmagamentos, anestésicos locais, e venenos; e as células satélites são também mais resistentes à isquemia que as miofibras.

Quando ativadas são capazes de cruzar a lâmina sarcolemal da miofibra em ambas as direções (LIPTON \& SCHULTZ, 1979) e migram consideráveis distâncias dentro do músculo (SCHULTZ et al., 1985; 1988). Este fato talvez explicasse a grande quantidade de núcleos nos miotubos, relatada nos resultados 
desta investigação, decorrentes, provavelmente, de células satélites migradas e que, inicialmente, se constituiriam em mioblastos e após, em miotubos.

BISCHOFF (1986), estudou unidades de célula satélite em cultura retirado de músculo de rato adulto esmagado, para identificar e caracterizar a sua mitogênese. Observou que a quantidade e a rapidez da regeneração dependeu dos parâmetros de ativação e do ciclo celular das células satélites, isto foi importante para compreender os fatores que governam o recrutamento e a proliferação destas células. Relatou também que injeção de mitogênico (extrato de músculo) também estimula o crescimento muscular neonatal de rato in vivo. Isto foi observado pelo aumento do número de mionúcleos por fibra depois de tratamento com o extrato de músculo. Também sugerem que o extrato de músculo estimula a fusão de mioblastos in vivo. Isto poderia evidenciar que células satélites quiescentes tornam-se ativadas por fatores de crescimento liberados por miofibrilas vizinhas lesadas.

A proliferação continuada das células satélites seria sustentada por fatores mitogenéticos como fator de crescimento de fibroblastos (FGF) e fator insulínico de crescimento (IGF) os quais seriam regulados pelo músculo após a lesão (JENNISCHE \& OLIVECRONA, 1987).

Muitas células satélites no músculo em regeneração proliferam dentro de "mangas" vazias de lâmina basal de miofibras em degeneração e este material teria importância como: a) suporte mecânico; b) reservatório de fatores de crescimento e c) substrato de macromoléculas favoráveis à miogênese.

Finalmente, o restabelecimento da irrigação e inervação do músculo em regeneração seria essencial para o crescimento normal e o seu funcionamento (GROUNDS, 1991).

Considerando a grande capacidade do USP na indução de vasos neoformados, quer nos parecer que parte da recuperação de fibras decorra deste fato. Acredita-se que parte da velocidade da regeneração decorra da ação do USP. Em primeiro lugar pela neoformação vascular que abreviaria a fase necrótica da lesão favorecendo a fibrose; e em segundo lugar aumentando o número de células satélites 
e sua transformação em mioblastos, estimulando igualmente a agregação dos mesmos em miotubos.

Para ganho de tempo do leitor em evidenciar a grande capacidade do USP de baixa intensidade na indução de formação de vasos neo-formados, bem como acelerar o processo cicatricial, junta-se aqui a Figura 25 com esta finalidade.

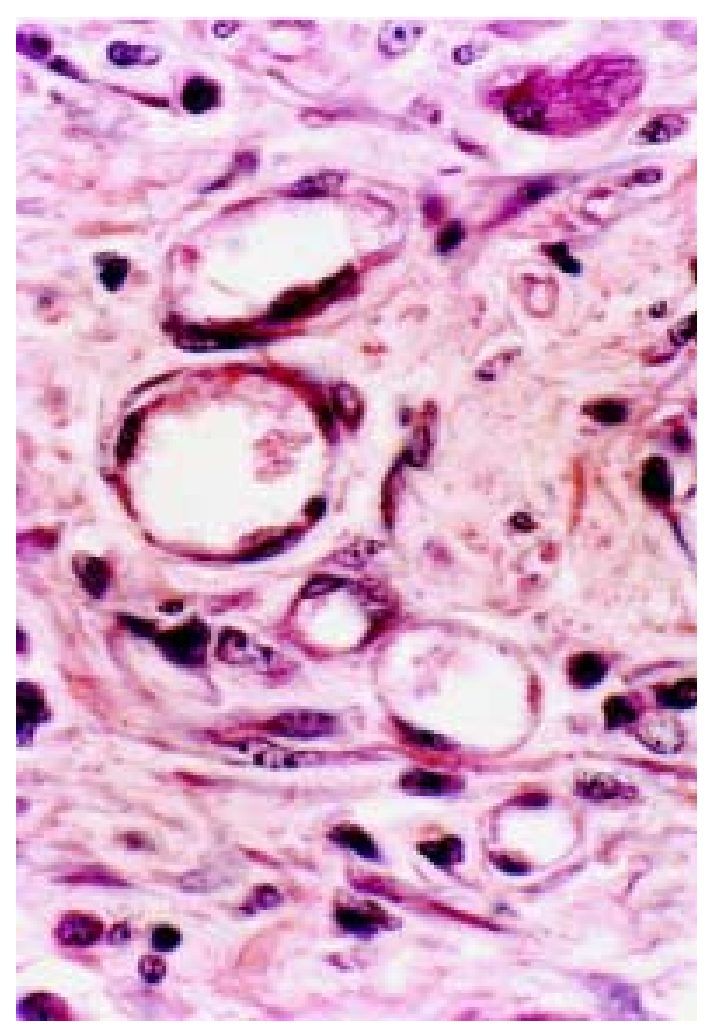

FIGURA 25 - Vasos neoformados induzidos pela ação do ultra-som pulsado em músculo estimulado por 3 dias, com conseqüente aceleração da inflamação. Aumento de 1200x.

Embora os conhecimentos sobre a regeneração do músculo estriado tenham progredido nos últimos anos, demonstrando a influência de diferentes fatores, acredita-se tratar de assunto altamente relevante, pois o progresso em quaisquer novos conhecimentos beneficiarão muito os tratamentos médicos e fisioterapêuticos.

A regeneração de fibras musculares esqueléticas tem sido documentada após vários tipos de lesões a que são submetidas. Com cada tipo de lesão, tanto os 
danos das fibras quanto a regeneração, não seriam avaliadas convenientemente segundo CARLSON \& FAULKNER (1983) senão mediante transplante total do músculo. Não compartilhamos com as idéias destes autores, porque com nossa metodologia conseguimos resultados demonstrativos da regeneração muscular.

Embora os estudos não sejam definitivos, o processo regenerativo parece seguir um determinado padrão.

Não resta dúvidas que os resultados desta pesquisa com o uso do USP de baixa intensidade demonstram a aceleração da velocidade da regeneração que pode ser caracterizado comparativamente nas fotomicrografias. Os músculos lesados nas suas fibras por incisões com o bisturi, regeneram mais precocemente quando se lhes aplica o USP.

Fica também demonstrado que o número de mitoses aumenta sob o efeito do USP, bem como o aparecimento precoce de miotubos e a migração de células satélites para a formação dos mesmos. Estes fatos decorrem, provavelmente da vascularização induzida pelo USP, a qual se fazem também mais intensa e precocemente nos animais estimulados por mais tempo. Verifica-se ainda, nos animais estimulados, a presença de grande número de células em mitose bem como o aparecimento de miofilamentos nos miotubos recém constituídos.

Nas fotomicrografias de células musculares íntegras fora da área da lesão, encontra-se ainda mitoses de células satélites, fato não encontradiço nos animais controles, não estimulados.

É intenção o prosseguimento nesta linha de pesquisa utilizando-se de animais isogênicos nos quais promover-se-ia o transplante de músculos seguido de estímulos com o USP e bloqueio de mitoses com injeções de mitostáticos. 


\section{CONCLUSÃO}

Os resultados, obtidos mediante a análise histopatológica da evolução temporal da regeneração de fibras musculares esqueléticas, produzidas experimentalmente no músculo glúteo de ratos, permitem admitir uma regeneração precoce das fibras musculares quando estimuladas pelo USP de baixa intensidade.

Há uma intensa formação neovascular, aumento do número de mitoses de células mioprecursoras, maior quantidade de miotubos com miofilamentos nos animais estimulados pelo USP, em comparação com o músculo de animais não estimulados, submetidos ao mesmo tipo de lesão e avaliados a iguais períodos evolutivos. 


\section{REFERÊNCIAS BIBLIOGRÁFICAS}

ALBROOK, D. (1962). An electron microscopic study of regenerating skeletal muscle. J. Anat., v.96, n.2, p.137-52.

ALVES, J.M. (1988). Efeitos da energia ultra-sônica na regeneração de pele de animal com queimadura por calor. São Carlos. Dissertação (Mestrado) - Escola de Engenharia de São Carlos/Faculdade de Medicina de Ribeirão Preto, Universidade de São Paulo.

ANDERSEN, J.L.; SCHJERLING, P.; SALTIN, B. (2000). Muscle, genes and athletic performance. Scientific American, v.283, n.3, p.30-7, Sept.

BENOIT, P.W.; BELT, W.D. (1970). Destruction and regeneration of skeletal muscle after treatment with a local anaesthetic bupivicaine (Marcaine). J. Anat., v.107, p.547-66.

BISCHOFF, R. (1975). Regeneration of single skeletal muscle fibers in vitro. Anat. Rec., v.182, p.215-236.

BISCHOFF, R. (1986). A satellite cell mitogen from crushed adult muscle. Developmental Biology. v. 115, p. 140-147.

BISCHOFF, R.; HEINTZ, C. (1994). Enhancement of skeletal muscle regeneration. Developmental Dynamics, v.201, p.41-54.

BISCHOFF, R. (1990). Interaction between satellite cells and skeletal muscle fibers. Development, v.109, p.943-52. 
BODINE-FOWLER, S. (1994). Skeletal muscle regeneration after injury - An Overview. Journal of Voice, v.8, n.1, p.53-62.

BRASSEUR, G.; ONOLFO, J.P.; COPIN, H.; LEPERCHEY, F.; BARBET, J.P. (1997). Degeneration and regeneration of striated muscle fibers in Duchenne muscular dystrophy. Bull. Assoc. Anat (Morphologie), v. 81, n.252, p.9-13 /Resumo.

CAMPION, D. R. (1984). The muscle satellite cell: a review. International Review of Cytology, v.87, p. 225-51.

CARLSON, B. M.; FAULKNER, J. A. (1983) The regeneration of skeletal muscle fibers following injury: a review. Medicine and Science in Sports and Exercise. v.15, n.3, p.187-98.

CARLSON, B. M. (1986). Regeneration of entire skeletal muscle. Federation Proceedings. v.45, n.5, p.1456-60.

CHOU, S. M.; NONAKA, I. (1977). Satellite cells and muscle regeneration in disease human skeletal muscle. Journal of the Neurological Sciences, v.34, p.131-45.

CHURCH, J. C. T. (1970). Cell populations in skeletal muscle after regeneration. Embryol. Exp. Morph. v.23, p.531-7.

CRISCO, J. J.; JOKL, P.; HEINEN, G. T.; CONNELL, M. D.; PANJABI, M. M. (1994). A muscle contusion injury model - biomechanics, phisiology and histology. The American Journal of Sports Medicine, v.22, n.5, p.702-10.

DANILOV, R.K.; ODINTSOVA, I.A.; NAIDENOVA, I.U.G. (1996). The regeneration of skeletal muscle tissue after a gunshot injury. Morfologia, v.110, n.5, p.86-90/Resumo.

DUARTE, L.R. (1987) Estimulação ultra-sônica do calo ósseo. São Carlos. Tese (Livre-Docência) - Escola de Engenharia de São Carlos, Universidade de São Paulo.

DUARTE, L.R. (1983). The stimulation of bone growth by ultrasound. New York, Archives of Orthopaedic and Traumatic Surgery, v.101, p.153-9.

DYSON, M. (1987). Mechanisms Involved in Therapeutic Ultrasound. Physiotherapy, v.73, n.3, p.116-20, Mar.

DYSON, M. (1990). Role of Ultrasound in Wound Healing. In: KLOTH, L.C. et al. (eds.). Altternatives in Wound Management. Phyladelphia: F. ${ }^{\text {a }}$ Davis. p.259-284. 
DYSON, M.; SUCKLING, J. (1978). Stimulation of tissue repair by ultrasound: a survey of the mechanisms involved. Physiotherapy, v. 64, n.4, p.105-8, apr.

FERRARI, A. L. (1987) Estudos dos mecanismos de cavitação em meio biológico. São Carlos, 133p. Dissertação (Mestrado) - Escola de Engenharia de São Carlos/Faculdade de Medicina de Ribeirão Preto, Universidade de São Paulo.

FISCHER, B.D.; BARACOS, V.E.; SHNITKA, T.K.; MENDRYK, S.W.; REID, D.C. (1990). Ultrastutural events following acute muscle trauma. Medicine and Science in Sports and Exercise. v.22, n.2, p.185-93.

FREDERICK, J. R. Ultrasound engineering. New York, John Willey \& Sons, 1965. $379 \mathrm{p}$.

FRIZZEL, L. A.; DUNN, F. (1984) Biphysics of ultrasound. In: Lehman J.F. Therapeutic heat and cold. 3.ed. London, Willians \& Wilkins. Cap. 8-10, p. 353562.

FUKADA, E.; YASUDA, I. (1957). On Piezoeletric Effect of Bone. Journal of Physical Society of Japan. v.12, n.10, p.1152-62, Oct.

GARTNER, P.L.; HIATT, J.L.(1999). Histologia. Rio de Janeiro, Guanabara Koogan.

GOUVÊA, C.M.C.P; VIEIRAL, P.M.N. \& AMARAL, A.C. (1998) Efeito do Ultrasom na recuperação de músculo tibial anterior de rato lesado. Rev. Univ. Alfenas, v.4, p.165-173.

GROUNDS, M.D. (1991). Towards understanding skeletal muscle regeneration. Pathol. Res. Pract. v.187, n.1, p.1-22.

HADAAD, S. (1992) Estímulo do testículo de ratos pré-púberes, púberes e adultos com ultra-som pulsado de baixa intensidade. Ribeirão Preto. Dissertação (Mestrado) - Faculdade de Medicina, Universidade de São Paulo.

HIKES, D. L; HEDRICK, W. R.; STARCHMAN, D. E. (1985) Ultrasound physics and instrumentations. New York, Churchill Livingstone. 247p.

HILL, C. R. (1972). Ultrasonic Exposure Threshold for Changes in Cell and Tissues. The Journal of the Acoustical Society of America, v.52, p.667-72.

HOLTZER, H.; MARSHAL, J.M.; FINCK, H. (1957). Analysis os myogenesis by the use of fluorescent antimyosin. J. Biophys. Biochem. Cytol. v.3, p.705-24. 
HURME, T.; KALIMO, H. (1992). Activation of myogenic precursor cells after muscle injury . Medicine and Sciences in Sports and Exercise, v.24, n.2, p.197205.

JENNISCHE, E.; OLIVECRONA, H. (1987). Transient expression of insulin-like growth factor I immunoreactivity in skeletal muscle cells during postnatal development in the rat. Acta Physiol. Scand. v.131, p.619-622.

JUNQUEIRA, L.C.; CARNEIRO, J. (1999) Histologia Básica. 9.ed. Rio de Janeiro, Guanabara Koogan.

KÄÄRIÄINEN，M.; KÄÄRIÄINEN，J.; JÄRVINEN，T.L.N.; SIEVÄNEN，H.; KALIMO, H.; JÄRVINEN, M. (1998). Correlation between biomechanical and structural changes during the regeneration of skeletal muscle after laceration injury. Journal Of Orthopaedic Research, v. 16, p. 197-206.

KONIGSBERG, I. R. (1961) Cellular differentiation in colonies derived from single cell platings of freshly isolated chick embryo muscle cells. Proc. Nat. Acad. Sci., v.47, p.1868-72.

KUREK, J.; BOWER, J.; ROMANELLA, M.; AUSTIN, L. (1996). Leukaemia inhibitory factor treatment stimulates muscle regeneration in the mdx mouse. Neurosci. Lett., , v.212, n.3, p.167-70.

LAWSON-SMITH, M. J.; McGEACHIE, J. K. (1998). The identification of myogenic cells in skeletal muscle, with emphasis on the use of tritiated thymidine autoradiography and desmin antibodies. J. Anat. , v.192, p.161-171.

LEFAUCHER, J. P.; SÉBILLE, A. (1995). The cellular events of injured muscle regeneration depend on the nature of injury. Neuromusc. Disord. v.5, n.6, p. 501509.

LEITE, A. J. (1989). Quantificação da ruptura celular produzida por Ultra-som em eritrócitos do sangue humano. Ribeirão Preto. Dissertação (Mestrado) Faculdade de Filosofia, Ciências e Letras, Universidade de São Paulo.

LIPTON, B.H.; SCHULTZ, E. (1979). Developmental fate of skeletal muscle satellite cells. Science, v.205, p.75-80.

MALTIN, C. HARRIS, J.B.; CULLEN, M.J. (1983). Regeneration of mammalian skeletal muscle following the injection of the snake-venom toxin, paipoxin. Cell. Tissue Res., v.232, p.565-77.

MASON, W. P. (1981). Piezoelectricity, its History and Applications. Journal Acoust. Soc. Am., v.70, p. 1561-6. 
MAURO, A. (1961). Satellite cells of skeletal muscle fibers. J. Biophys. Biochem. Cytol. v.9, p.493-5.

MAURO, A.; SHAFIQ, S.A.; MIHORAT, A. T. (eds). (1970). Regeneration of striated muscle and myogenesis. Amsterdan: Excerpta Medica, p.118-121.

MOTIMER JR, A.; DYSON, M. (1988). The effect of therapeutic ultrasound on calcium uptake in fibroblasts. Ultrasound in Medicine and Biology, v.14, n.6, p.499-506.

MUIR, A. R.; KANJI, A. H. M.; ALBROOK, D. (1965) The struture of the satellite cell in skeletal muscle. J. Anat., v.99, p.435-444.

NIKOLAOU, P.K.; MACDONALD, B.L.; GLISSON, R.R.; SEABER, A.V.; GARRET JR, W.E. (1987). Biomechanical and histological evaluation of muscle after controlled strain injury. The American Journal of Sports Medicine, v.15, n.1, p.9-14.

NOONAN T.J.; BEST, T.M.; SEABER, A.V.; GARRETT JR., W.E. (1994). Identification of a threshold for skeletal muscle injury. The American Journal of Sports Medicine, v.22, n.2, p.257-261, mar./apr.

OKUNO, E.; CALDAS, I.L.; CHOW, C. Física para ciências biológicas e biomédicas. São Paulo, Harba, 1986. 490 p.

ONO, K.; ABE, J.I.; KAGAWA, H.; HIZAWA, K. (1993). Imunohistochemical analysis of myoblast proliferation and differentiation in experimental skeletal muscle regeneration. Zentralbl. Pathol., v.139, p.231-237.

RANTANEN, J.; THORSSON, O.; WOLLMER, P.; HURME, T.; KALIMO, H. (1999). Effects of therapeutic ultrasound on the regeneration of skeletal myofibers after experimental muscle injury. The American Journal of Sports Medicine, v.27, n.1, p.54-59.

RICHARDSON, P.D. (1989). Piezoelectric plymers. IEEE. Medicine and Biology Magazine, jun.

ROSS, M.H.; ROMRELL, L.J. (1993). Histologia: texto e atlas. 2.ed. São Paulo, Panamericana.

SARVAZYAN, A. P. (1983). Some General Problems of Biological Action of Ultrasound. IEEE Transactions on Sonics and Ultrasonics, v.30, n.1, p.2-12, Jan.

SCHULTZ, E.; ALBRIGHT, D.J.; JARYSZAK, D.L.; DAVID, T.L. (1988). Survival of satellite cells in whole muscle transplants. Anat. Rec., v.222, p.12-7. 
SCHULTZ, E.; JARYSZAK, D.L.; VALLIERE, C.R. (1985). Response of satellite cells to focal skeletal muscle injury. Muscle Nerve, v.8, p.217-22.

SCHULTZ, E.; JARYSZAK, D. L. (1985). Effects of skeletal muscle regeneration on the proliferation potential of satellite cells. Mech Ageing Dev., v.30, n.1, p.6372, Apr.

SILVA, O. L. (1987). Estudo do mecanismo da ação do ultra-som na estimulação do tecido ósseo. São Carlos. Dissertação (Mestrado) - Escola de Engenharia de São Carlos, Universidade de São Paulo.

TER HAAR, G. (1978). Basic physics of therapeutic ultrasound. Physiotherapy, vol. 64, n. 4., p.100-103.

TER HAAR, G.; DANIELS, S.; EASTAUGH, K.C.; HILL, C.R. (1982). Ultrassonically induced cavitation in vivo. BR. J. Cancer, vol.45, supl.5, n.151.

TER HAAR, G. (1987). Physic of Therapeutic Ultrasound. London, Physiotherapy, v. 73, n.3, Mar.

TER HAAR, G. (1987). Tissue regenerations. In: REPACHOLI, M.H. et al. Ultrasound. Medical aplications, biological effects and hazard potential. New York, Plenun Press.

WALKER, B.E. (1963.). Skeletal muscle regeneration in young rats. Am. J. Anat., v.133, p.369-78.

WELLS, P. N. T. Biomedical ultrasonics. London: Academic Press, 1977. 635 p.

WILLIAMS, P.L. WARWICK, R.; DYSON, M.; BANNISTER, L.H. (1995). Gray Anatomia. Rio de Janeiro, Guanabara Koogan. v.1.

WILLIAMS, R. A. (1983). Ultrasound: biological effect and potential hazards. London, Academic Press.

XAVIER, C.; DUARTE, L. R. (1983). Estimulação ultrasônica do calo ósseo. Revista Brasileira Ortopédica, v.18, n.3, p.73-80, maio/jun.

YOUNG, S.R.; DYSON, M. (1978). Macrophage Responsiveness to Therapeutic Ultrasound. Ultrasound in Medicine and Biology, v.16, n.8, p.809-816, 190.

YOUNG, S. R. (1990). The effect of therapeutic ultrasound on the biological mechanisms envolved in dermal repair. London. Thesis $(\mathrm{PhD})$ - University of London. 
ZISKIN, M. C. (1985). Clinics in diagnostic ultrasound. In: NYBORG, W. L.; ZISKIN, M. C. Biological effects of Ultrasound. New York, Churchill Livingstone.

ZISKIN, M. C. (1989). Report on the safety of the SAPHS device. Temple University Medical School, Philadelphia, PA, USA. (not published). 